\title{
Role of B Cells and Antibodies in Acquired Immunity against Mycobacterium tuberculosis
}

\author{
Jacqueline M. Achkar ${ }^{1}$, John Chan $^{1,2}$, and Arturo Casadevall ${ }^{1,2}$ \\ ${ }^{1}$ Department of Medicine, Albert Einstein College of Medicine, Bronx, New York 10461 \\ ${ }^{2}$ Departments of Microbiology and Immunology, Albert Einstein College of Medicine, Bronx, New York 10461 \\ Correspondence: jacqueline.achkar@einstein.yu.edu
}

Accumulating evidence has documented a role for B cells and antibodies (Abs) in the immunity against Mycobacterium tuberculosis (Mtb). Passive transfer studies with monoclonal antibodies (mAbs) against mycobacterial antigens have shown protection against the tubercle bacillus. B cells and Abs are believed to contribute to an enhanced immune response against $M t b$ by modulating various immunological components in the infected host including the T-cell compartment. Nevertheless, the extent and contribution of B cells and Abs to protection against $M t b$ remains uncertain. In this article we summarize the most relevant findings supporting the role of B cells and Abs in the defense against Mtb and discuss the potential mechanisms of protection.

\begin{abstract}
$A$ pproximately one-third of the world's Apopulation is infected with M. tuberculosis $(M t b)$. It is generally thought that the majority of this population harbors latent bacilli, of which only $\sim 10 \%$ develop the disease active tuberculosis (TB) during their lifetime. The interplay of immunological components resulting in contained and stable latent $M t b$ infection (LTBI) is incompletely understood. Cell-mediated immunity (CMI) plays a key role in the defense against Mtb (Lewinsohn et al. 2011; Ottenhoff 2012; Ottenhoff and Kaufmann 2012), but increasing evidence suggests that CMI is not the sole defense mechanism against the tubercle bacillus. In humans, an intact CMI does not consistently protect against disease, and in $M t b$-infected nonhuman primates, cell-mediated responses do not significantly correlate with
\end{abstract}

the outcome of infection (Lin et al. 2009). Furthermore, not all individuals with LTBI and impaired CMI develop TB. Current and newly developed TB vaccines targeting CMI have limited efficacy in humans, and vaccine-induced cell-mediated responses often lack significant correlation with efficacy (Colditz et al. 1994; Fletcher et al. 2013; Tameris et al. 2013). These findings support a role for additional immune components in the protection against $M t b$ beyond that contributed by CMI.

The strong evidence for $\mathrm{CMI}$ as the main defense mechanism against $\mathrm{TB}$ has historically set up a false dichotomy that posited no role for humoral immunity (Maglione and Chan 2009; Achkar and Casadevall 2013). The general belief that, because of their extracellular location, antibodies (Abs) are not involved in the

Editors: Stefan H.E. Kaufmann, Eric J. Rubin, and Alimuddin Zumla

Additional Perspectives on Tuberculosis available at www.perspectivesinmedicine.org

Copyright (C) 2015 Cold Spring Harbor Laboratory Press; all rights reserved; doi: 10.1101/cshperspect.a018432

Cite this article as Cold Spring Harb Perspect Med 2015;5:a018432 
J.M. Achkar et al.

protection against intracellular pathogens further limits an open view for the role of B cells and $\mathrm{Ab}$-mediated immunity against $\mathrm{Mtb}$. However, this view has been largely discredited and abandoned based on abundant evidence from many systems (reviewed in Casadevall 2003). We note that although immunoglobulins are a major product of B cells, these lymphocytes can contribute to the host immune response to $M t b$ via $\mathrm{Ab}$-independent mechanisms (Bosio et al. 2000; Maglione et al. 2007; Maglione and Chan 2009; Russo and Mariano 2010; Almeida et al. 2011; Zhang et al. 2012). Whereas $\mathrm{Ab}$-independent B-cell effects are largely accepted by the field, the historical controversy revolving around the role for B cells and the humoral immune response in the defense against $M t b$ typically relates solely to that of Abs. Therefore, in this review, we refer to $\mathrm{B}$ cells and Abs as distinct immunological elements simply to stay within the currently operating intellectual framework in the $M t b$ field.

Abs have many mechanisms by which they can modify the outcome of bacterial intracellular pathogenesis, ranging from opsonization to signaling through Fc receptors (FcRs) (reviewed in Casadevall 1998, 2003; Nimmerjahn and Ravetch 2008). Furthermore, just as for other facultative intracellular pathogens, there is plenty of evidence for an extracellular phase of $\mathrm{Mtb}$ during which it can be directly targeted by Abs (Smith et al. 2000; Casadevall 2003; Grosset 2003; Karakousis et al. 2004; Kim et al. 2010; Ahmad et al. 2011; Hoff et al. 2011; Driver et al. 2012). Importantly, Abs have been shown to play an important role in the defense against other intracellular pathogens such as Salmonella, Chlamydia, Cryptococcus, and Histoplasma spp. (reviewed in Casadevall 2003), and for some of these pathogens such as Salmonella, vaccines protecting through $\mathrm{Ab}$-mediated immunity have ultimately been developed and licensed (Collins 1974).

A classic example for a paradigm shift from an exclusive CMI-centric view toward acceptance of an important role for Ab-mediated immunity occurred in the field of mycology, in which B cells and Abs were also once considered to have no protective role. As in TB, it was not possible to establish a consisted protective role for humoral immunity with polyclonal sera against fungi such as Candida albicans and Cryptococcus neoformans (reviewed in Casadevall 1995). However, the implementation of hybridoma technology produced immunoglobulins that revealed the existence of protective monoclonal antibodies (mAbs) and challenged this dogma (reviewed in Casadevall 1995; Casadevall and Pirofski 2012a). Also like Mtb, many of the medically relevant fungi such as C. neoformans and Histoplasma capsulatum are facultative intracellular pathogens, and the control of infection with these fungi requires vigorous granuloma formation indicative of CMI. The breakthrough in medical mycology came from the work of Françoise Dromer and colleagues who identified a protective $\mathrm{Ab}$ against $C$. neoformans, a finding that suggested the notion that humoral immunity could mediate protection if the right $\mathrm{Ab}$ response was elicited (Dromer et al. 1987). Two decades later humoral immunity had been shown to be protective against numerous fungi (reviewed in Casadevall and Pirofski 2012a), and two vaccines against $C$. albicans are currently in clinical trials, both of which are believed to mediate protection by eliciting a protective $\mathrm{Ab}$ response (reviewed in Cassone and Casadevall 2012). Parallel developments appear to be occurring in the TB field. In the following sections we discuss the complexity of humoral immunity in $\mathrm{TB}$, the evidence for a role of Abs and $\mathrm{B}$ cells in the protection against $\mathrm{TB}$, and the potential mechanisms for Ab-mediated immunity. Based on the discussed findings we posit a role for B cells and Abs in the protection against $\mathrm{TB}$ and suggest that an effective immunity against $M t b$ includes a humoral component.

\section{COMPLEXITY OF THE HUMORAL IMMUNE RESPONSES AGAINST Mtb}

TB serological studies provide abundant data that $M t b$ induces a humoral immune response to a wide variety of mycobacterial antigens (Ags) in humans and animals. Although humans and nonhuman primates show considerable heterogeneity in $\mathrm{Ab}$ responses against $\mathrm{Mtb}$ (Lyashchenko et al. 1998; Ireton et al. 2010; 
Kunnath-Velayudhan et al. 2010, 2012), Ab responses in other animal species such as elephants or deer are more homogeneous (Lyashchenko et al. 2008, 2012). Animal and human serum transfer studies have provided inconsistent and sometimes contradictory data regarding a role of $\mathrm{Abs}$ in the protection against $\mathrm{TB}$ (reviewed in Glatman-Freedman and Casadevall 1998). Several observations suggest explanations for these inconsistent results. Just as in other diseases such as fungal infections in which the $\mathrm{Ab}$ response is complex and involves both protective and nonprotective Abs (reviewed in Casadevall and Pirofski 2012a), interstudy inconsistencies might have been due to the variability typically found in polyclonal preparations. Nonprotective or even disease-enhancing Abs can also negatively or positively influence the efficacy of protective Abs when these act in combinations (Nussbaum et al. 1996; Chow et al. 2013), further highlighting the difficulty when evaluating polyclonal preparations. The discovery that fungal Ags targeted by protective mAbs do not always elicit an Ab response during a natural infection (Nosanchuk et al. 2003), could be another explanation for negative results when transferring immune sera from vaccine studies. On the other hand, little is known about the role and complexity of protective Abs in $M t b$ infection models that mimic human infection by developing both natural LTBI and TB without modification of immunity. And last, $\mathrm{Ab}$ responses against $\mathrm{Mtb}$ can be speciesspecific (Lyashchenko et al. 2007, 2008), and thus the transfer of $\mathrm{Ab}$ preparations obtained from a species different than the one studied would also result in considerable variability.

\section{EVIDENCE FOR A ROLE OF HUMORAL IMMUNITY IN THE PROTECTION AGAINST TB}

The efficacy of Ab-mediated immunity against a microbe can be established by the three general approaches as proposed by Casadevall (2004): (1) Establish that passive administration of a microbe-specific Ab modifies the course of infection to the benefit of the host; (2) ascertain that the presence of microbe-specific Abs in a host is associated with decreased susceptibility to infection and disease; and (3) establish that increased susceptibility to disease exists in hosts with deficits in humoral immunity and/or B cell function. For TB evidence for all three criteria has now been documented (Table 1).

Passive transfer studies with Abs against mycobacterial Ags. Evidence that passive Ab transfer can improve the outcome of experimental mycobacterial infection in mice was documented by eight independent groups for mAbs against mycobacterial Ags (Teitelbaum et al. 1998; Pethe et al. 2001; Chambers et al. 2004; Hamasur et al. 2004; Williams et al. 2004; Buccheri et al. 2009; Lopez et al. 2009; Balu et al. 2011) and three recent studies with polyclonal IgG or serum within the same species (mice) or from humans to mice (Roy et al. 2005; Guirado et al. 2006; Olivares et al. 2006) (Table 2). Studies that have probed the role of protective mAbs have used a variety of parameters to assess their efficacy including prolongation in survival time (Teitelbaum et al. 1998; Chambers et al. 2004; Hamasur et al. 2004), reduced dissemination (Pethe et al. 2001), reduced tissue pathology (Chambers et al. 2004; Lopez et al. 2009; Balu et al. 2011), and reduced mycobacterial burden as measured by colony forming units (CFU) (Hamasur et al. 2004; Williams et al. 2004; Buccheri et al. 2009; Lopez et al. 2009; Balu et al. 2011). Of note, one study also compared the effect of $\mathrm{mAb}$ with IFN- $\gamma$ and the combination of both (Balu et al. 2011). Although a significant reduction of lung CFU was seen with the combination of $\mathrm{mAb}$ and IFN- $\gamma$, and a borderline effect for $\mathrm{mAb}$ alone, no significant CFU reduction was seen with IFN- $\gamma$ alone, pointing toward a potentially important interplay between $\mathrm{Ab}$ and cytokine in the protection against $\mathrm{TB}$. Recent passive $\mathrm{Ab}$ transfer studies in mice using homologous or heterologous (human) sera have also shown protection against experimental infection (Roy et al. 2005; Guirado et al. 2006; Olivares et al. 2006). However, none of these monoclonal or polyclonal $\mathrm{Ab}$ transfer studies include a comparison to the efficacy of BCG (Bacille Calmette-Guérin) vaccination in mice. When viewed from this context we note that whereas vaccination with BCG often induc- 
J.M. Achkar et al.

Table 1. Evidence of antibody-mediated protection against Mycobacterium tuberculosis infection

\begin{tabular}{|c|c|c|}
\hline Criterion & Evidence & References \\
\hline \multirow[t]{2}{*}{$\begin{array}{l}\text { Passive } \mathrm{Ab} \text { transfer } \\
\text { studies }\end{array}$} & $\begin{array}{l}\text { Eight independent groups have shown } \\
\text { protection and/or modification of the } \\
\text { course of mycobacterial infection in mice } \\
\text { with passive transfer of mAbs to } \\
\text { mycobacterial antigens (Table } 2 \text { ). }\end{array}$ & $\begin{array}{l}\text { Teitelbaum et al. 1998; Pethe et al. 2001; } \\
\text { Chambers et al. 2004; Hamasur et al. } \\
\text { 2004; Williams et al. 2004; Buccheri } \\
\text { et al. 2009; Lopez et al. 2009; Balu } \\
\text { et al. } 2011\end{array}$ \\
\hline & $\begin{array}{l}\text { Three independent groups have recently } \\
\text { shown protection in mice with passive } \\
\text { transfer of immune polyclonal sera. }\end{array}$ & $\begin{array}{l}\text { Roy et al. 2005; Guirado et al. 2006; } \\
\text { Olivares et al. } 2006\end{array}$ \\
\hline \multirow[t]{2}{*}{$\begin{array}{l}\text { High Ab titer associated } \\
\text { with reduced } \\
\text { susceptibility }\end{array}$} & $\begin{array}{l}\text { AM-containing conjugate vaccine elicits } \\
\text { Ab response that reduces susceptibility } \\
\text { to infection. }\end{array}$ & $\begin{array}{l}\text { Hamasur et al. 2003; Glatman- } \\
\text { Freedman et al. } 2004\end{array}$ \\
\hline & $\begin{array}{l}\text { BCG as well as } M t b \text { antigen-containing } \\
\text { conjugate and DNA/RNA vaccines elicit } \\
\text { cellular and humoral immune responses } \\
\text { and improve outcome of infection. }\end{array}$ & $\begin{array}{l}\text { Huygen et al. 1996; Hamasur et al. 2003; } \\
\text { Glatman-Freedman et al. 2004; Xue } \\
\text { et al. 2004; de Valliere et al. 2005; Giri } \\
\text { et al. 2006; Grover et al. 2006; Teixeira } \\
\text { et al. 2006; Chang-hong et al. 2008; } \\
\text { Kohama et al. 2008; Palma et al. 2008; } \\
\text { Niu et al. } 2011\end{array}$ \\
\hline \multirow{6}{*}{$\begin{array}{l}\text { Increased susceptibility } \\
\text { in hosts with } \mathrm{Ab} \\
\text { deficits }\end{array}$} & $\begin{array}{l}\text { Peak of childhood TB is temporally } \\
\text { correlated with nadir in maternal Ab. }\end{array}$ & $\begin{array}{l}\text { Beyazova et al. 1995; Cruz and Starke } \\
\text { 2007; Donald et al. } 2010\end{array}$ \\
\hline & $\begin{array}{l}\text { Lack of Abs against certain mycobacterial } \\
\text { antigens is associated with TB } \\
\text { dissemination in children and adults. }\end{array}$ & $\begin{array}{l}\text { Sada et al. 1990; Costello et al. 1992; } \\
\text { Boggian et al. 1996; Gupta et al. 1997; } \\
\text { Dayal et al. } 2008\end{array}$ \\
\hline & $\begin{array}{l}\text { Lack of early humoral immune response in } \\
\text { Mtb-infected nonhuman primates } \\
\text { predicts high likelihood for reactivation } \\
\text { disease. }\end{array}$ & Kunnath-Velayudhan et al. 2012 \\
\hline & $\begin{array}{l}\text { B-cell-deficient mice are more susceptible } \\
\text { to TB. }\end{array}$ & $\begin{array}{l}\text { Vordermeier et al. 1996; Maglione et al. } \\
\text { 2007, } 2008\end{array}$ \\
\hline & $\begin{array}{l}\text { Polymeric IgR-deficient mice loose } \\
\text { mycobacterial antigen-specific IgA } \\
\text { response in saliva and are more } \\
\text { susceptible to respiratory BCG infection. }\end{array}$ & Tjarnlund et al. 2006 \\
\hline & $\begin{array}{l}\text { IgA deficiency increases susceptibility to } \\
\text { mycobacterial infection in mice. }\end{array}$ & $\begin{array}{l}\text { Rodriguez et al. 2005; Buccheri et al. } \\
2007\end{array}$ \\
\hline \multirow[t]{5}{*}{ Other } & Existence of mycobactericidal Abs & Conti et al. 1998 \\
\hline & $\begin{array}{l}\text { FcR-mediated phagocytosis promotes } \\
\text { phagolysosomal fusion. }\end{array}$ & Armstrong and Hart 1975 \\
\hline & $\begin{array}{l}\text { FcR-mediated phagocytosis increases } \\
\text { macrophage } \mathrm{Ca}^{2+} \text { signaling and } \\
\text { intracellular killing. }\end{array}$ & Malik et al. 2000 \\
\hline & $\begin{array}{l}\text { Higher FcyRIA expression in (i) subjects } \\
\text { with TB compared with LTBI, and (ii) } \\
\text { subjects before compared with after } \\
\text { antituberculous treatment. }\end{array}$ & Sutherland et al. 2013; Cliff et al. 2013 \\
\hline & $\begin{array}{l}\text { IgG bound to BCG enhances oxygen release } \\
\text { in phagosomes and antimycobacterial } \\
\text { activity of alveolar macrophages. }\end{array}$ & Suga et al. 1996 \\
\hline
\end{tabular}

Data in table modified with permission from Achkar and Casadevall 2013.

mAb, monoclonal Ab; AM, arabinomannan; BCG, Bacillus Calmette-Guérin; Mtb, M. tuberculosis; TB, tuberculosis; FcR, Fc receptor; LTBI, latent $M t b$ infection. 
B Cells and Antibodies in TB
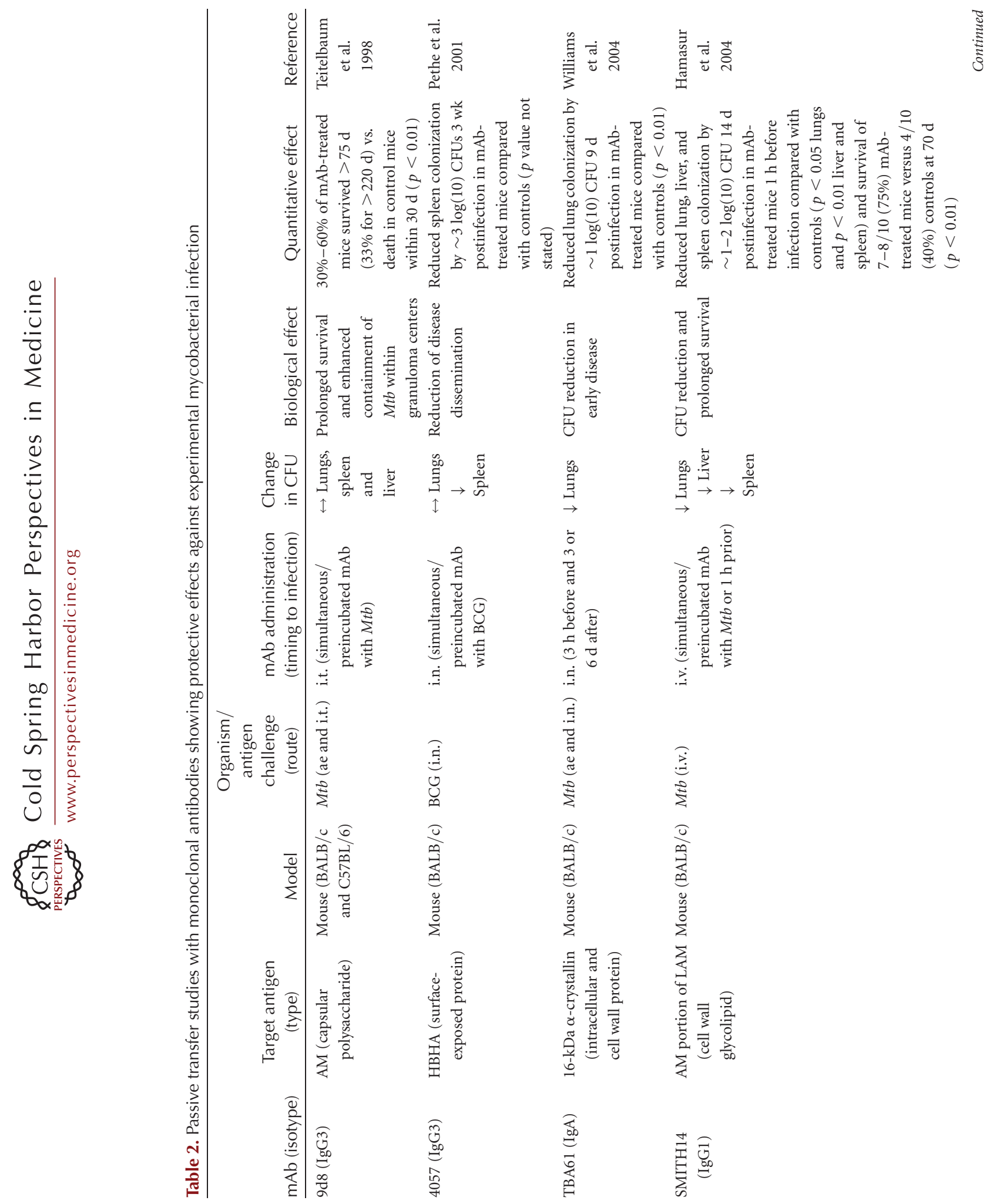
J.M. Achkar et al.
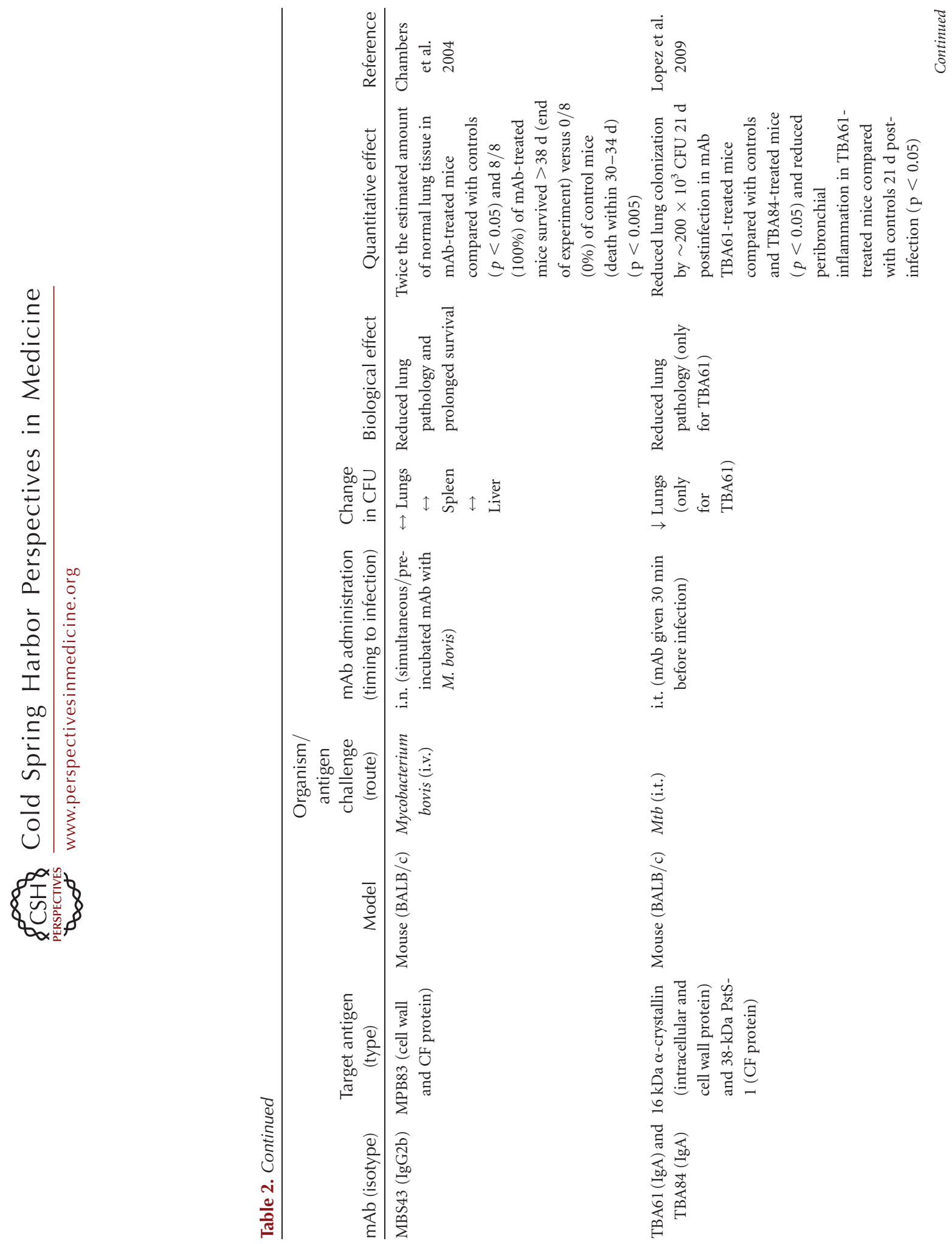
B Cells and Antibodies in TB
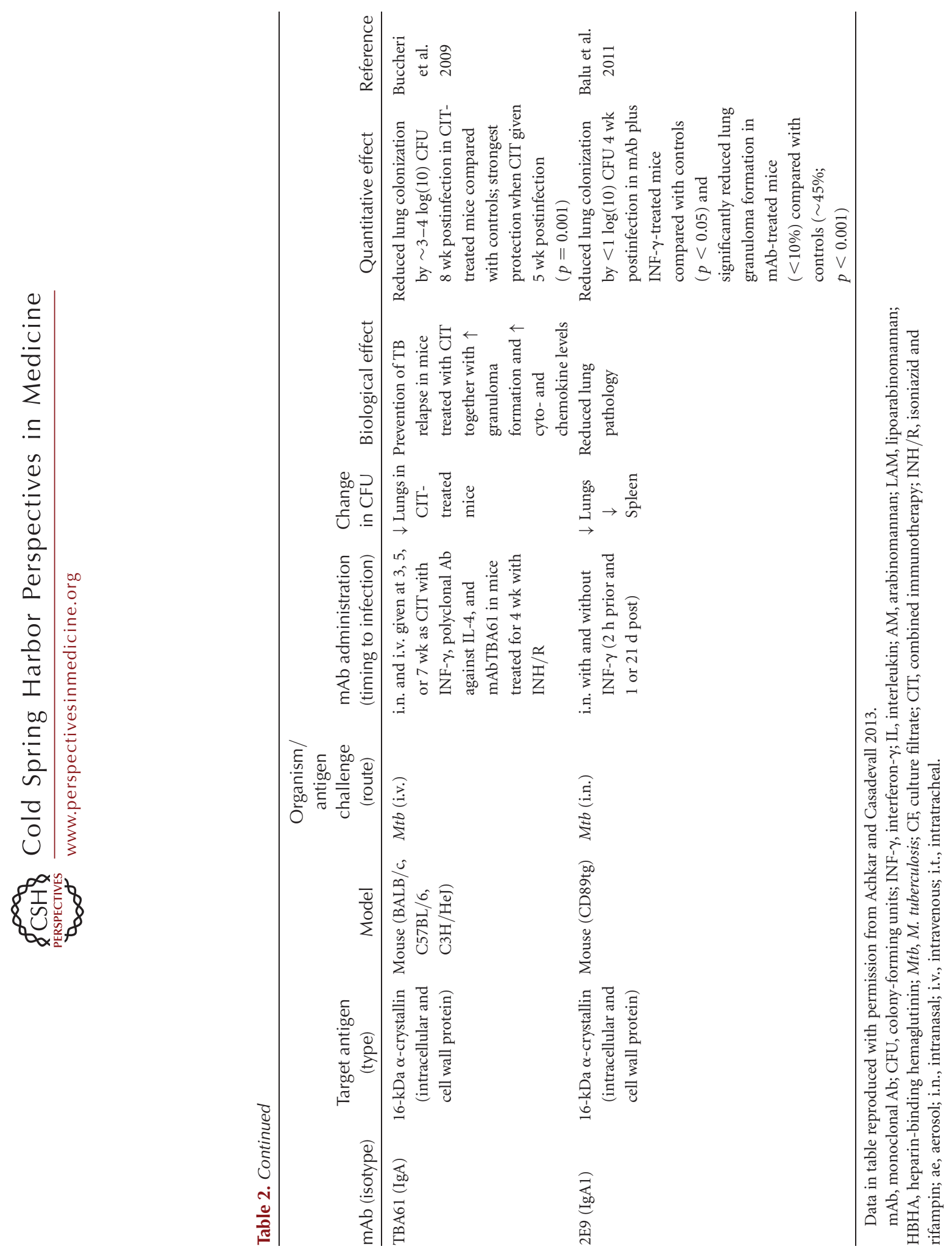
J.M. Achkar et al.

es variable reduction in CFU at $30 \mathrm{~d}$ of infection (Keyser et al. 2011), the effects of passive $\mathrm{mAb}$ varied from being less than, comparable, and greater than described for BCG vaccines (reviewed in Achkar and Casadevall 2013). Additional transfer studies with more standardized designs, and ideally an additional BCG-vaccinated control group, are needed to allow for better comparison of the effects of Ab-based protection against $\mathrm{Mtb}$.

Association of the presence of Abs against Mtb with decreased susceptibility to infection and disease. Mice immunized with conjugate vaccines, containing arabinomannan (AM), a mycobacterial capsular, and cell wall polysaccharide, develop high $\operatorname{IgG}$ titers against $\mathrm{AM}$ and are more TB-resistant than control mice (Hamasur et al. 2003; Glatman-Freedman et al. 2004. When comparing one of these AM conjugate vaccines to BCG comparable efficacy was demonstrated (Hamasur et al. 2003), providing additional evidence for the potential of certain Abs to protect against Mtb. Furthermore, it is noteworthy that BCG and other mycobacterial Ag-based vaccines including DNAvaccine elicit both humor$\mathrm{al}$ and cellular responses (reviewed in Achkar and Casadevall 2013). In contrast to most TB vaccine studies, de Valliere et al. (2005) investigated the role of Abs induced after BCG vaccination. They showed that BCG-induced Abs enhance effects of both the innate and cell-mediated immune responses against mycobacteria. Thus, although protection of TB vaccines is often attributed only to the cellular response, one cannot rule out that the humoral response also contributed to host defense.

Association of increased susceptibility to disease with deficits in humoral immunity and B-cell function. The peak of vulnerability to TB in early childhood coincides with a nadir in Ab (Beyazova et al. 1995; Fairchok et al. 1995; Cruz and Starke 2007; Donald et al. 2010). This association is supported by a study showing that the lack of Abs against the mycobacterial cell wall glycolipid lipoarabinomannan (LAM) correlates significantly with disseminated TB in age-matched children (Costello et al. 1992). Also of note is that patients with HIV-associated $\mathrm{TB}$, which tends to progress faster and frequent- ly disseminates, also have lower Ab titers against LAM or AM (Boggian et al. 1996; Yu et al. 2012), although this association warrants further investigation. A role of $\mathrm{Ab}$ in protection is also supported by serological studies finding lower $\mathrm{Ab}$ levels in children and adults with the occurrence of disseminated and extrapulmonary $\mathrm{TB}$ (Sada et al. 1990; Gupta et al. 1997; Dayal et al. 2008; Ziegenbalg et al. 2013). These findings suggest that Abs against certain Ags could reduce the risk of TB dissemination in humans. Such a hypothesis is supported by studies in animal models. For example, the mycobacterial surface protein heparin-binding hemagglutinin adhesin (HBHA) promotes $M t b$ dissemination in mice, whereas passive transfer with a $\mathrm{mAb}$ against HBHA reduces extrapulmonary dissemination (Pethe et al. 2001) (Table 2). Furthermore, our group has recently shown that an AM-conjugate vaccine prevented $M t b$ dissemination in mice, an effect that was not observed with BCG vaccination (R Prados-Rosales, unpubl.).

Perhaps the closest to a state of pure B-cellrelated deficiency in humans is the clinical entity of hypogamaglobulinemia (Bruton 1952; Good and Zak 1956; Conley et al. 2009). Although clinical studies have reported TB in persons with immunoglobulin (Ig) deficiency, these patients typically present with infections caused by bacteria commonly associated with human diseases such as Streptococcus pneumonia (Good and Zak 1956; Conley et al. 2009). On diagnosis of hypogammaglobulinemia, sustained periodic IVIG therapy is required for preventing infection-associated mortality (Bruton 1952; Good and Zak 1956). Such therapies can obscure the potential significance of $\mathrm{Ab}$ deficiency in the defense against $M t b$. Patients not receiving this standard Ig therapy will likely succumb to "endogenous" colonizing pathogens and not $M t b$. Therapy with Rituximab, which depletes $\mathrm{CD}_{20}{ }^{+} \mathrm{B}$ cells and has been used widely in the treatment of B-cell malignancies and autoimmune diseases (Czuczman and Gregory 2010; Townsend et al. 2010), has not been associated with increased susceptibility to $M t b$. In contrast, it has been amply showed that anti-TNF therapies enhances the risk for devel- 
oping reactivation TB (Keane et al. 2001). Of note, however, is that studies including individuals receiving Rituximab have not revealed an increased risk for infection to bacterial pathogens (reviewed in Rubbert-Roth 2012; Ruderman 2012; Schoels et al. 2012; Isaacs 2013) including those that are known colonizers of the host, and which defense has been shown to be highly B-cell-dependent (Bruton 1952; Good and Zak 1956). Hence, the absence of increased susceptibility to TB with these therapies cannot be used to argue against a role for Ab-mediated immunity. The mechanisms underlying this observation are likely multifactorial and remain to be determined. It is conceivable that they could be due to specific pharmacokinetic property of Rituximab or the inability of this monoclonal antibody to deplete the long-lived CD20- plasma cells.

In animal models, IgA-deficient mice are more susceptible to BCG infection than wildtype controls (Rodriguez et al. 2005). Polymeric IgR-deficient mice vaccinated with the mycobacterial protein PstS-1 had lower PstS-1-specific IgA levels in their saliva and were more susceptible to BCG infection than vaccinated wild-type mice (Tjarnlund et al. 2006), and IgA administration in the setting of interleukin-4 (IL-4) and interferon- $\gamma$ (IFN- $\gamma$ ) administration conferred protection against $M t b$ in mice (Buccheri et al. 2007). Furthermore, mice lacking the $y$-chain of an activating receptor for the Fc portion of Abs (FcyR) are more susceptible to $M t b$ infection and advanced pulmonary disease than wild-type mice (Maglione et al. 2008).

Studies with B-cell-deficient mice mostly support the role of B cells in TB immunity but some have also provided inconsistent results. Two of four published studies report that Bcell-deficient mice are more susceptible to experimental infection (Vordermeier et al. 1996; Maglione et al. 2007). A different study challenging with $M t b$ after isoniazid therapy found no difference between B-cell-deficient and wildtype mice (Johnson et al. 1997). One study found that the pulmonary histopathology was more pronounced in B-cell-knockout compared with wild-type mice after low-dose $M t b$ infection (Bosio et al. 2000). Of note is that humans with pulmonary TB were also found to have lower percentages of peripheral blood $\mathrm{B}$ cells compared with asymptomatic individuals with and without presumed $M t b$ infection (Corominas et al. 2004; Hernandez et al. 2010). These findings, together with the observation that an infected host mounts a robust $\mathrm{Ab}$ response against $M t b$, provide strong support for the notion that B cells actively participate in the immune response to $M t b$.

\section{INFLUENCE OF B CELLS ON OTHER IMMUNE CELLS IN $M t b$ INFECTION}

There is ample evidence that T cells and macrophages play a critical role in the defense against $M t b$ infection and disease. However, B cells, just as $\mathrm{T}$ cells, interact with various immune cells, thus contributing to the defense mechanisms. We note that the extent of cellular interactions renders it challenging to quantify the amount of protection contributed by a single specific immune cell population. Studies involving various animal TB models have provided compelling evidence that T-cell deficiency produces strong susceptibility phenotypes (Flynn and Chan 2001; Cooper 2009; Ernst 2012). A recent report showing that $\mathrm{T}$ cells play a central role in coordinating the antimycobacterial effects of a variety of immune cells during the innate phase of the host response further underscores the significance of this lymphocyte population in defense against $M t b$ (Yao et al. 2014). The importance of T cells in defense against the tubercle bacillus is further supported by enhanced susceptibility of humans defective in T-cell-activating elements as a result of mutation in the receptors of IFN- $\gamma$ and IL-12 (Abel and Casanova 2000; Casanova and Abel 2002; Fortin et al. 2007). It is curious that in these naturally occurring human models, the genotypes are mostly associated with infection with relatively weakly virulent mycobacteria such as environmental bacilli and BCG. This observation could be due to the higher probability of exposure to environmental mycobacteria than to $M t b$, and that $\mathrm{BCG}$-osis is the result of direct inoculation of the vaccine during immunization. 
J.M. Achkar et al.

Although macrophages play an important role in initiating IL-12/IFN- $\gamma$-related antimycobacterial functions, it was reported that nonselective depletion of this immune cell in a murine TB model resulted in enhanced protection against pulmonary $\mathrm{TB}$, whereas selective ablation of activated macrophages increased susceptibility (Leemans et al. 2001, 2005). In addition, although it was shown that mutations at or near the Scl11a1 (Nramp1) locus, a gene that confers macrophage resistance to mycobacteria, resulted in susceptibility to $M t b$ in certain human populations (Fortin et al. 2007), this allele appears to play no role in the control of the tubercle bacillus in mice (North et al. 1999). These results suggest that valid testing of the significance of specific immunological factors in defense against $M t b$ may require an appropriate host, adding yet another layer of complexity to studies aimed at deciphering protective antituberculous response.

$B$ cells, in addition to being a rich source of Abs, can modulate the immune response by virtue of their ability to present Ags and produce a wide variety of cytokines. These modulating functions play important roles in affecting the development of immune cells including $\mathrm{T}$ cells, neutrophils, macrophages, and dendritic cells (reviewed in Maglione and Chan 2009; Kozakiewicz et al. 2013b). B-cell-deficient mice are more susceptible to $M t b$ infection, and this deficiency results in enhanced lung immunopathology and increased pulmonary neutrophil infiltration and IL-10 production (Maglione et al. 2007). The importance of B cells in the regulation of neutrophil influx at the site of infection is supported by another study showing an abnormally rapid neutrophil migration in Bcell-deficient mice, and demonstrating the capacity of B cells to down-regulate neutrophil motility (Kondratieva et al. 2010). The capacity of B cells to down-regulate neutrophil motility appears critical for the effectiveness of BCG vaccination in mice (Kondratieva et al. 2010). The B-cell-deficient phenotypes are reversible by adoptive transfer of $\mathrm{B}$ cells from infected wildtype (WT) C57BL/6 mice, establishing B-cell specificity. Reversal of these lung phenotypes is associated with the presence of Ig in serum of recipient mice without a requirement for pulmonary homing of transferred cells (Maglione et al. 2007). These observations suggest that the rescue effect of transferred $B$ cells is at least partially caused by Ab-mediated immune regulation and indicate that humoral immunity plays a significant role in the defense against $M t b$. This notion is further supported by our recent observations that tissue neutrophilia in B-celldeficient mice can be reversed by administration of sera from tuberculous mice (Kozakiewicz et al. 2013a).

A role for B cells regulating T cells in immune responses to $M t b$ is supported by our finding that in chronic infection, CD4 T-cell proliferation and IFN- $\gamma$ production in B-cell-deficient mice are significantly different than that in WTs (Maglione and Chan 2009). Mice deficient for the inhibitory Fc $\gamma$ RIIB $\left(\right.$ FcyRIIB $^{-/-}$) are more resistant to $\mathrm{Mtb}$ compared with WT controls (Maglione et al. 2008). These findings correlated with enhanced pulmonary Th1 responses, evidenced by increased IFN- $\gamma$-producing $\mathrm{CD}^{+}{ }^{+} \mathrm{T}$ cells, and suggests that Abs can regulate $\mathrm{CD} 4 \mathrm{Th} 1$ response in acute $\mathrm{TB}$ through engagement of FcR by Ab-Ag complexes. Furthermore, in mice and humans, features of germinal center B cells suggest that they are immunologically active (Ulrichs et al. 2004; Maglione et al. 2007). We and others have shown that B cells are a conspicuous cellular component in lung granuloma of humans, nonhuman primates, and mice with TB (Gonzalez-Juarrero et al. 2001; Ulrichs et al. 2004; Tsai et al. 2006; Flynn 2010). It has recently been shown in both human and mouse models that B-cell nodules in tuberculous lung tissues are populated with CXCR5 $^{+}$T cells (Slight et al. 2013). This T-cell population, which is directed to infected lungs via expression of CXCR5, plays a role in the control of $M t b$ by promoting macrophage activation and lymphoid nodule formation (Slight et al. 2013).

Accumulating experimental evidence has revealed the significance of the interaction between B and Tlymphocytes in the germinal center in an immune response, including that developed against microbial pathogens (Vinuesa et al. 2005; Ma et al. 2012). The clinical 
relevance of this interaction was shown recently in the qualitative and quantitative analysis of the germinal center reaction in HIV (human immunodeficiency virus) models (Vinuesa 2012; Cubas et al. 2013; Locci et al. 2013; Pillai 2013; Schmitt and Ueno 2013). The results of these studies revealed that the nature of the Bcell humoral immunity in response to antigens, particularly as it related to the generation of broadly neutralizing antibodies, was highly dependent on the $\mathrm{T}$ follicular helper cells, whose development occurs in the germinal center ( Vinuesa 2012; Cubas et al. 2013; Locci et al. 2013; Pillai 2013; Schmitt and Ueno 2013). Indeed, abnormalities of the B-cell and humoral immune response in individuals infected with HIV have been documented (Moir and Fauci 2009). Thus, it remains possible that the aberrant B-cell compartment of the host immune response contributes to the susceptibility of HIV-infected individuals to the tubercle bacillus. Similarly, because of this B:T interaction, it is not straightforward to determine the relative contribution of these two lymphocyte populations in the defense against $M t b$. It is possible that B cells and humoral immunity could account, at least in part, for the enhanced susceptibility to $M t b$ in individuals afflicted with T-cell-deficient states other than that associated with HIV infection. Together, these observations indicate that protective mechanisms against the tubercle bacillus are complex and most certainly involve redundancy, rendering quantification of the relative contribution to the overall host resistance to $M t b$ by specific immunological factors difficult. This difficulty is further compounded by the highly interactive nature of immune cells.

\section{MECHANISMS OF Ab-MEDIATED PROTECTION AGAINST Mtb}

Mycobacteria are potentially susceptible to mechanisms of Ab-mediated immunity irrespective of whether they are in their intracellular or extracellular phase (Fig. 1). Internalization of Mtb through FcgR after Ab opsonization has been reported to trigger phagolysosomal fusion (Armstrong and Hart 1975) and promote intra- cellular killing in a mechanism that increases $\mathrm{Ca}^{2+}$ signaling (Malik et al. 2000). Alveolar macrophages ingesting BCG opsonized with IgG manifested an enhanced oxidative burst, a phenomenon that could translate into increased microbicidal activity (Suga et al. 1996). Stimulation of surface receptors can affect the fate of internalized microbes. In this regard, killing of the intracellular parasite Toxoplasma gondii is enhanced by stimulation of Fc1RII-CD23 receptors by immune complexes (Vouldoukis et al. 2011), and there is evidence that activation of the same receptor enhances activity against mycobacteria (Mossalayi et al. 2009). Ab could also help host defense by potentiating the effect of cell-mediated immunity. In this regard, there is some evidence that Abs to BCG antigens can potentiate both adaptive and innate cell-mediated immune responses against mycobacteria (de Valliere et al. 2005). Additional evidence comes from the observation that sera from individuals who were exposed to TB and had high, but not low IgG to tuberculin blocked proliferation of PBMCs when stimulated with tuberculin (Encinales et al. 2010). For other pathogens, such as Chlamydia spp., specific $\mathrm{Ab}$ can enhance cell-mediated responses by altering cytokine responses and promoting Ag presentation through enhanced uptake and processing (Igietseme et al. 2004), and similar mechanism could apply to mycobacteria. In addition, there is also clear evidence for an extracellular phase of $M t b$ during which it can be directly targeted by Abs (Smith et al. 2000; Casadevall 2003; Grosset 2003; Karakousis et al. 2004; Kim et al. 2010; Ahmad et al. 2011; Hoff et al. 2011; Driver et al. 2012).

Engagement of distinct FcyRs can divergently affect the susceptibility for TB, suggesting that targeting FcyRs can be a means to enhance TB immunity (Maglione et al. 2008). In contrast to the inhibitory FcyRIIB ${ }^{-/}$strain, mice lacking the $y$-chain of activating FcyRs are more susceptible to $M t b$ infection with exacerbated immunopathology and increased production of the anti-inflammatory cytokine IL-10 (Maglione et al. 2008). Because different isotypes and IgG subclasses engage different types of FcyR, the class of the $\mathrm{Ab}$ response is likely to 
J.M. Achkar et al.

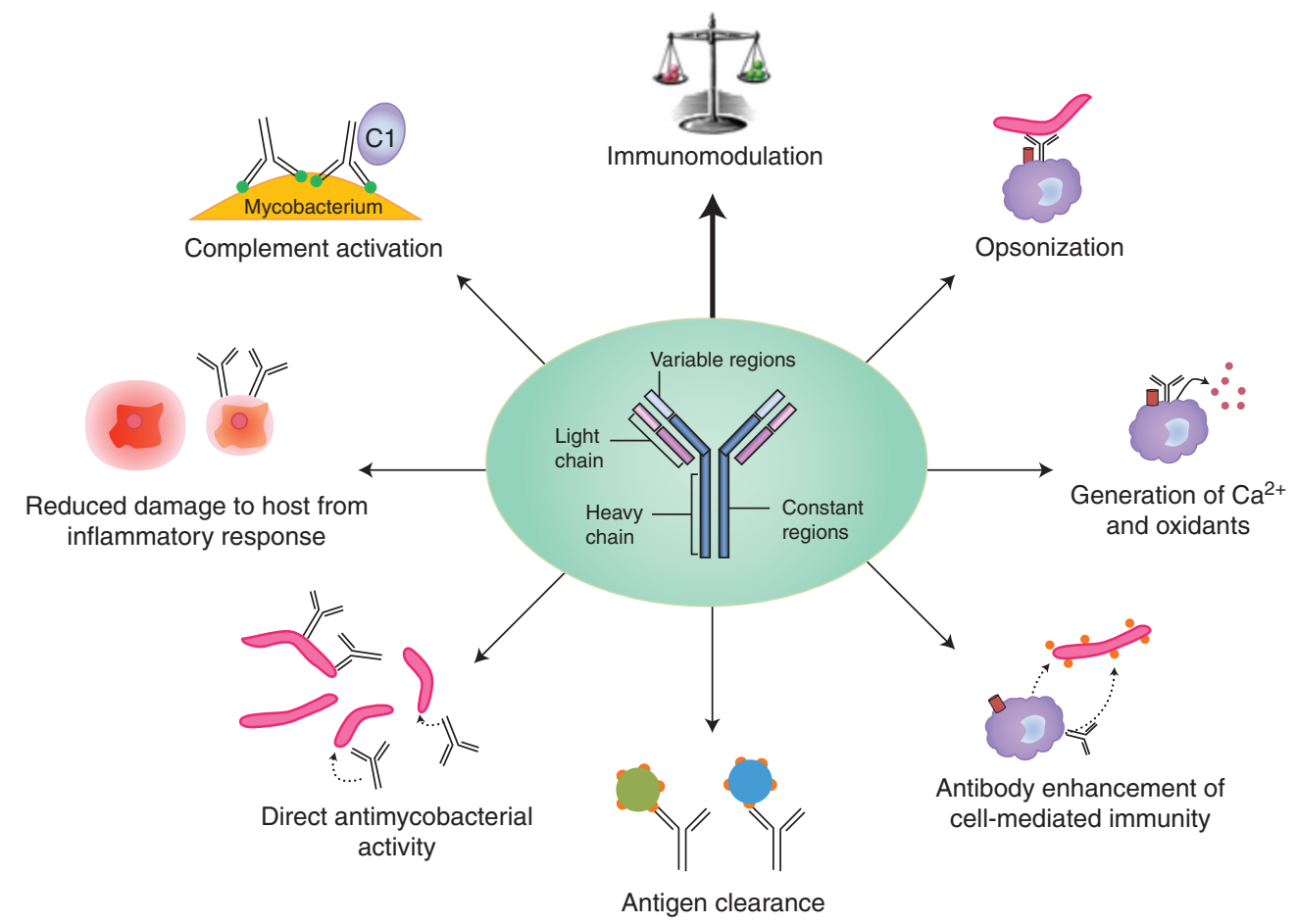

Figure 1. Illustration of the various reported mechanisms of antibody-mediated protection against Mycobacterium tuberculosis such as opsonization (Armstrong and Hart 1975), increase of macrophage $\mathrm{Ca}^{2+}$ signaling (Malik et al. 2000), and release of oxidants (Suga et al. 1996; Mossalayi et al. 2009) enhancing intracellular killing, other mechanisms enhancing cell-mediated immunity (de Valliere et al. 2005; Encinales et al. 2010), clearance of immunomodulatory mycobacterial antigens (Glatman-Freedman et al. 2000), direct antimycobacterial activity (Conti et al. 1998), and activation of complement (Hetland et al. 1998; Carroll et al. 2009; Manivannan et al. 2012).

be important in resistance. This is consistent with the well-established data that Ag-Ab interactions with FcR can modulate the immune response, which has been exploited in the treatment of a variety of diseases, most notably neoplastic and autoimmune disorders (Kalergis and Ravetch 2002; Rafiq et al. 2002; Clynes 2005; Dhodapkar et al. 2005). In fact, a recent multisite human gene expression study found that expression of FcyRIA was significantly and consistently higher in subjects with TB compared with those with LTBI, regardless of HIV coinfection (Sutherland et al. 2013). These findings were consistent with another study showing a significant reduction in FcyRIA expression in TB cases after antituberculous treatment when compared with pretreatment expression (Cliff et al. 2013). FcyRIA is predominantly expressed by monocytes and macrophages, is induced by IFN- $\gamma$, promotes Ab-dependent cytotoxicity, mediates the clearance of immune complexes, and may have been responsible for the control of $M t b$ after Ab-mediated phagocytosis observed in earlier studies (Armstrong and Hart 1971). Overall, these study results of FcyRs in both humans and animals further support a protective role of the humoral immune component against $M t b$.

Other functions of Ab could also contribute to protection against mycobacteria. For example, specific $\mathrm{Ab}$ forms $\mathrm{Ag}-\mathrm{Ab}$ complexes that can then be cleared by the reticuloendothelial system. Evidence for the potential of this mechanism comes from the observation that $\mathrm{Ab}$ can promote the clearance of mycobacterial Ags that can impair host immunity through their immu- 
nomodulatory properties (Glatman-Freedman et al. 2000). For both fungi and bacteria specific Abs binding to surface components have been shown to modulate gene expression (McClelland et al. 2010; Yano et al. 2011). In the case of the bacterium Streptococcus pneumonia agglutinating non-opsonic Abs trigger bacterial death through quorum sensing-related mechanisms (Yano et al. 2011). Abs mimicking fungal killer toxin have been reported to be microbicidal to Mtb (Conti et al. 1998). Although such Abs would not be expected to occur in an immune response to $\mathrm{Mtb}$ infection, the fact that some Abs can directly kill mycobacteria provides a precedent for notion that some Abs on the mycobacterial surface could trigger similar effects.

Abs are known to be powerful modulators of the inflammatory response. Given that the outcome of mycobacterial infection is highly dependent on the tissue inflammatory response, it is likely that $\mathrm{Ab}$ responses could have beneficial or deleterious effects depending on their ability to influence inflammation. The inflammatory properties of Abs are complex and depend on their effect on microbial inoculum and their effector functions of the constant region (isotype). In general, IgMs are thought to be pro-inflammatory through their high complement-activating capacity (Ciurana et al. 2004), whereas IgG can be pro- or anti-inflammatory depending on the complement-activating capacity and type of FcR receptor engaged (Lux et al. 2010; Ballow 2011). Several studies have established that specific Abs to mycobacteria can modulate complement activation. The binding of complement to BCG can be enhanced by Ab with IgG > IgM (Carroll et al. 2009). Among patients with TB, the ability of $\mathrm{Ab}$ to trigger complement activation on BCG correlated with IgG2 but not IgM (Hetland et al. 1998). Human IgG has also been shown to promote complement activation on Mtb, which was associated with increased phagocytosis by macrophages (Manivannan et al. 2012).

It is possible to conceptualize how Abs with pro- and anti-inflammatory properties could influence the outcome of infection by considering these properties in the context of the dam- age-response framework. This framework posits that damage is maximal at the extremes of the immune response, with disease occurring when damage reaches a threshold to affect homeostasis (Casadevall and Pirofski 2003). In the case of TB, caseous necrosis and miliary disease represents extremes of too much and too little inflammatory response, respectively (Casadevall and Pirofski 2003; Achkar and Jenny-Avital 2011). Hence, pro- and anti-inflammatory Abs could mediate beneficial or deleterious effects depending on where the host is on the curve of damage versus immune response. The need for the right balance of inflammatory response to control $M t b$ infection is further supported by a recent study showing that although the proinflammatory cytokine tumor necrosis factor (TNF) is critical in the host defense against $\mathrm{TB}$, its excess leads to enhanced disease in zebrafish and humans (Roca and Ramakrishnan 2013). Taking the importance of the right balance of the combined immune responses to $M t b$ into consideration, Abs that are proinflammatory could help hosts that respond with too little inflammation, whereas those that are antiinflammatory could help hosts with exuberant inflammatory responses that result in tissue destructions (Fig. 2). Studies assessing the pro- and anti-inflammatory properties of Abs against $M t b$ are warranted to further elucidate the potential value of such Abs in disease states at opposite ends of the immune competency spectrum.

\section{CHARACTERISTICS OF PROTECTIVE Abs AGAINST Mtb}

The Ab parameters that contribute to protection include amount, specificity, affinity, and isotype. For $M t b$, very few $m A b s$ have been characterized in detail and consequently the difficulty to identify trends in the characteristics of protective Abs to $M t b$. However, it is possible to discern some themes. Protective Abs to Mtb recognize at least four different antigens. The murine isotypes IgM, IgG1, IgG3, and IgA have each been shown to protect against TB (Table 2 ). The finding that an IgG3 to AM lost protective efficacy when converted to IgG2a provides 
J.M. Achkar et al.
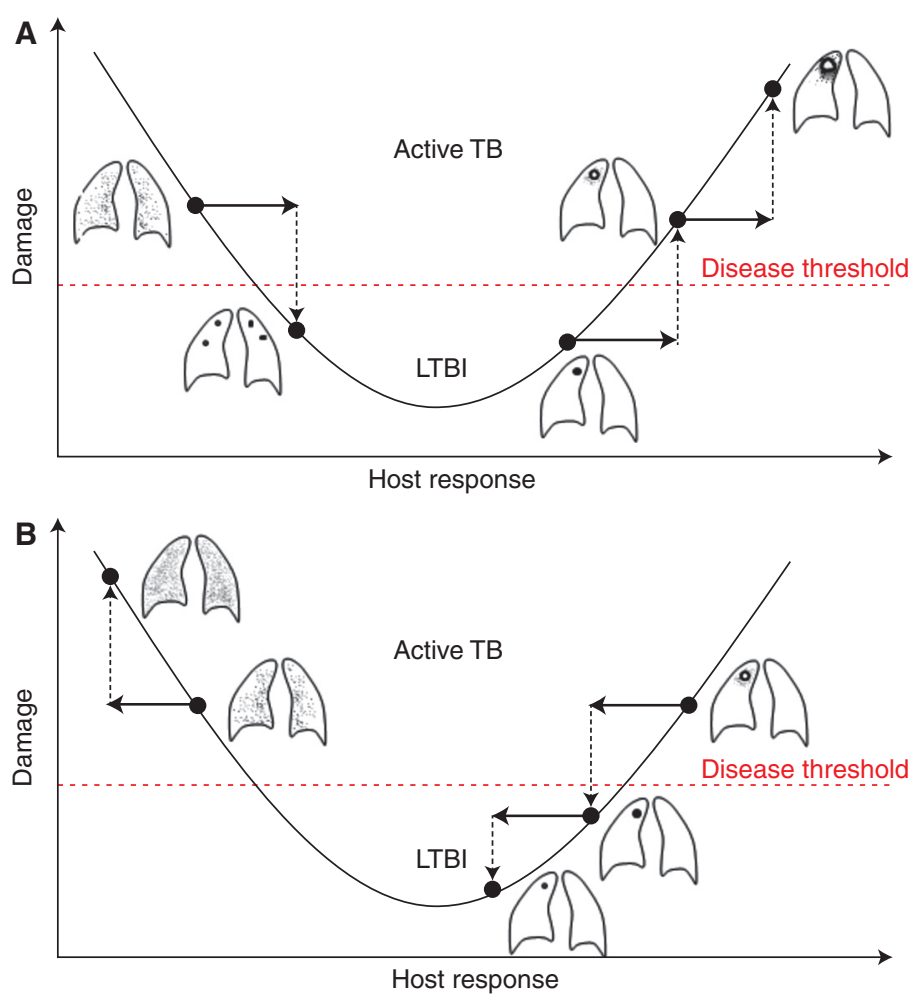

Figure 2. Interpretation of the potential function of pro- and anti-inflammatory antibodies against $M t b$ in the context of the damage-response framework. (A) Potential effects of a proinflammatory antibody with enhanced inflammation leading, on the one hand, to the improvement from disseminated/miliary TB in an immunocompromised host (left) to localized granuloma formation and, on the other hand, to progression from granuloma to caseous necrosis in the more immunocompetent host (right). (B) Potential effects of an antiinflammatory antibody leading to worsening TB dissemination in the immunocompromised host who has already reduced inflammation (left), but improved containment of local disease from caseous necrosis to granuloma formation in the more immunocompetent host with a strong inflammatory response (right). LTBI, latent TB infection. (Figure reproduced with permission from Achkar and Casadevall 2013.)

support for the notion that the constant region type has an important role in the activity of the $\mathrm{Ab}$ against $\mathrm{Mtb}$. (Schwebach 2002). An additional example of this phenomenon is the observation an IgA against the $16-\mathrm{kDa} \alpha$-cristallin was active against $M t b$, whereas an $\operatorname{IgG} 1 \mathrm{mAb}$ to the same epitope had no protective efficacy (Williams et al. 2004). Intranasal administration of an IgAl combined with IFN- $\gamma$ significantly ameliorated lung $\mathrm{H} 37 \mathrm{Rv}$ infection in mice transgenic for human CD89m but not in CD89-negative littermate controls, providing evidence that IgA-mediated protection required CD89 (Balu et al. 2011). The fact that IgA can protect against pulmonary $M t b$ infection is im- portant given the role of this isotype in mucosal immunity. Evidence that the amount of $\mathrm{Ab}$ is critical for protection comes from the observation of prozone-like effects in passive experiments in mice (Schwebach 2002).

\section{PERSPECTIVE ON IMPACT OF Abs AT THE VARIOUS Mtb INFECTION STATES}

Based on the known functions of Abs and the results of various studies we envision that $\mathrm{Ab}$ mediated immunity can serve a protective role against $M t b$ at various states of infection. Early in infection Abs could enhance host defenses by promoting phagocytosis through $\mathrm{FcR}$, a process 
that is known to increase intracellular killing and rapid uptake and processing of mycobacterial Ags. Similarly, Abs could activate complement, a process that would further promote phagocytosis and cellular recruitment to the site of infection. Given that mycobacterial polysaccharides and lipopolysaccharides are powerful immunomodulators that can interfere with the development of effective immune response, the presence of $\mathrm{Ab}$ to these Ags could contribute to host defense by promoting their clearance. Abs can function as pro- and anti-inflammatory molecules depending on their ability to activate $\mathrm{FcR}$, and this effect could be beneficial by heightening an effective inflammatory response or down-modulating runaway granuloma formation, which has the capacity to destroy tissues. We anticipate that $\mathrm{Ab}$ could have different roles depending on the immunological state of the host. For example, the proinflammatory effects of Ab-mediated immunity may help protect immunologically naïve hosts during initial infection. In this regards, naturally occurring $\mathrm{Ab}$, in particular IgM, is critical for defense against many infectious diseases (Casadevall and Pirofski 2012b) and could have an important role in protection against $M t b$ by promoting an early inflammatory response. In contrast, IgG elicited by vaccines would be expected to function primarily through FcR engagement. At this time the relative importance of these mechanisms is unknown, and it is possible that they differ from host to host. However, given that Abs have the capacity to modulate practically all aspects of the interaction between $M t b$ and its host, there is a high likelihood that this arm of the adaptive immune response can make a major contribution to host defense. Hence, there is a need for additional studies of $\mathrm{Ab}$ function and its potential role on both defense against and pathogenesis of mycobacterial infections.

\section{PERSPECTIVE FOR A ROLE OF Abs IN TB VACCINE EFFICACY AND TB TREATMENT}

Vaccines based solely on induction of $\mathrm{T}$ cells have not been successful to date. One possible explanation is that immunity requires a layered defense including a multipronged approach to obtain effective protection by a TB vaccine. In mice, as discussed above, B cells and Ig are important components of anti-TB immunity capable of modulating various aspects of host response against Mtb (Maglione and Chan 2009; Achkar and Casadevall 2013; Kozakiewicz et al. 2013 b). In view of these observations, it would be prudent to explore the possibility that B cells or Abs may play a role in engendering protection during vaccination against $M t b$, regardless of the importance of humoral immunity in optimal control of a natural tuberculous infection in humans. Indeed, BCG has been shown to be ineffective in engendering protection in B-celldeficient CBA/xid mice against $M t b$ challenge (Kondratieva et al. 2010) and BCG immunization in B-cell-deficient $\mu \mathrm{MT}$ mice elicits a CD4 Th1 response that is inferior to that in the wild types (Kozakiewicz et al. 2013a). Understanding the B-cell and humoral immunity during $M t b$ infection and immunization and harnessing such responses might lead to strategies and protocols required for the development of a much needed effective TB vaccine.

The ideal role of vaccine-induced neutralizing Abs would be the prevention of both infection in naïve individuals and progression to disease in $M t b$-infected individuals. Whether this is an achievable goal, and to what extent humoral immunity with specific isotypes would be required, is unclear with the current state of knowledge. Given the heterogeneity of human hosts and their humoral immune response, as well as the complexity of TB pathogenesis, it is possible that a cocktail of induced Abs against various targets and with various functions would provide higher protective efficacy than a single type of Ab. One of the likely most promising targets would include the $M t b$ capsular polysaccharide AM, as our group has recently shown that immunization with a conjugate vaccine containing this antigen protects mice better against $M t b$ infection than immunization with BCG.

An additional promising role of Abs would lie in their use as adjunctive treatment of $\mathrm{TB}$, especially in the setting of drug resistance. Such treatment could potentially shorten treatment duration and improve cure rates. Ab ther- 
J.M. Achkar et al.

apy against TB would likely have to be based on mAbs given the unpredictable heterogeneity of polyclonal serum preparations. Ab-based therapies have revolutionized the treatment of certain malignancies and autoimmune diseases (reviewed in Chan and Carter 2010; Weiner et al. 2010), and two mAbs have been approved for the treatment of infectious diseases (reviewed in Casadevall et al. 2004; Saylor et al. 2009). Furthermore, recent data, generated by our group and others, provide evidence that a combination of mAbs against different epitopes can enhance protective effects against infectious pathogens (Chow et al. 2013; Pohl et al. 2013). Thus, just as for vaccines, Ab-based therapy against TB will also be likely most effective if targeting multiple epitopes and/or antigens. Furthermore, for a beneficial impact on the disease, pro- versus anti-inflammatory mAbs might have to be selected taking the level of host inflammatory response to TB into account (Fig. 2). To move the field of therapeutic Abs ahead, various mAbs will need to be generated, characterized, optimized, and tested individually and in combination in vitro before being evaluated for their protection against experimental TB in animal models.

\section{SUMMARY}

When taking into account the older data (Glatman-Freedman and Casadevall 1998; GlatmanFreedman 2006), the fact that for other facultative intracellular pathogens such as fungi and Salmonella spp. Ab-mediated immunity has been shown to be important, the complexity of $\mathrm{Ab}$ responses to mycobacteria and more recent studies (Table 1), it is difficult to avoid the conclusion that humoral immunity has an important role in the protection against TB. When weighing the evidence, positive studies are much more significant than negative studies given that protective and nonprotective Abs exist and that the Ab response to $\mathrm{Mtb}$ is heterogeneous. In fact, the most straightforward interpretation of negative studies is that the particular serum or vaccine used in that study did not result in Ab-mediated protection. In contrast to negative studies, positive studies pro- vide direct evidence for the ability of Ab-mediated immunity to contribute to the host defense against TB. Consequently, we interpret the available data to indicate that $\mathrm{TB}$ vaccines that induce Ab-mediated immunity as well as Ab-based therapy could result in enhanced protection. We note that the protective mechanisms against the tubercle bacillus are complex and highly interactive, rendering quantification of the relative contribution of $\mathrm{B}$ cells and Abs to the overall host resistance to $M t b$ difficult at this time. However, what is certain is that the TB field cannot go forward ignoring the contribution of $\mathrm{Ab}$ mediated immunity if progress is going to be made in understanding the basis of host resistance and the design of future vaccines.

\section{ACKNOWLEDGMENTS}

This work was supported by funds from the National Institutes of Health $(\mathrm{NIH}) /$ National Institute of Allergy and Infectious Diseases (NIAID) (AI-067665 and AI-105684 to J.M.A., AI063537 and AI094745 to J.C., and AI-033774, AI-052733, and AI-033142 to A.C.), the National Heart, Lung, and Blood Institute (NHLBI) (HL-059842 to A.C.), the Center for AIDS Research (CFAR) at the Albert Einstein College of Medicine (AI-51519 to J.M.A.), the Aeras TB vaccine foundation (J.M.A. and A.C.), and the Food and Drug Administration (FDA) (1U18 FD004012/01 to J.M.A.). A.C. is also the recipient of a Bill \& Melinda Gates Grand Challenge award and TB Vaccine Accelerator Program award. We thank Anke Ziegenbalg for her graphic assistance with the figures.

\section{REFERENCES}

Abel L, Casanova JL. 2000. Genetic predisposition to clinical tuberculosis: Bridging the gap between simple and complex inheritance. Am J Hum Genet 67: 274-277.

Achkar JM, Jenny-Avital ER. 2011. Incipient and subclinical tuberculosis: Defining early disease states in the context of host immune response. J Infect Dis 204 (Suppl): S1179-S1186.

Achkar JM, Casadevall A. 2013. Antibody-mediated immunity against tuberculosis: Implications for vaccine development. Cell Host Microbe 13: 250-262.

Ahmad Z, Fraig MM, Bisson GP, Nuermberger EL, Grosset JH, Karakousis PC. 2011. Dose-dependent activity of 
pyrazinamide in animal models of intracellular and extracellular tuberculosis infections. Antimicrob Agents Chemother 55: 1527-1532.

Almeida LP, Trombone AP, Lorenzi JC, Rocha CD, Malardo T, Fontoura IC, Gembre AF, Silva RL, Silva CL, Castelo AP, et al. 2011. B cells can modulate the CD8 memory $\mathrm{T}$ cell after DNA vaccination against experimental tuberculosis. Genet Vaccines Ther 9: 5.

Armstrong JA, Hart PD. 1971. Response of cultured macrophages to Mycobacterium tuberculosis, with observations on fusion of lysosomes with phagosomes. J Exp Med 134: 713-740.

Armstrong JA, Hart PD. 1975. Phagosome-lysosome interactions in cultured macrophages infected with virulent tubercle bacilli. Reversal of the usual nonfusion pattern and observations on bacterial survival. J Exp Med 142: 1-16.

Ballow M. 2011. The IgG molecule as a biological immune response modifier: Mechanisms of action of intravenous immune serum globulin in autoimmune and inflammatory disorders. J Allergy Clin Immunol 127: 315-323; quiz 324-315.

Balu S, Reljic R, Lewis MJ, Pleass RJ, McIntosh R, van Kooten $\mathrm{C}$, van Egmond M, Challacombe S, Woof JM, Ivanyi J. 2011. A novel human IgA monoclonal antibody protects against tuberculosis. J Immunol 186: 3113-3119.

Beyazova U, Rota S, Cevheroglu C, Karsligil T. 1995. Humoral immune response in infants after BCG vaccination. Tuber Lung Dis 76: 248-253.

Boggian K, Fierz W, Vernazza PL. 1996. Infrequent detection of lipoarabinomannan antibodies in human immunodeficiency virus-associated mycobacterial disease. Swiss HIV cohort study. J Clin Microbiol 34: 1854-1855.

Bosio CM, Gardner D, Elkins KL. 2000. Infection of B celldeficient mice with CDC 1551, a clinical isolate of Mycobacterium tuberculosis: Delay in dissemination and development of lung pathology. J Immunol 164: 64176425.

Bruton OC. 1952. Agammaglobulinemia. Pediatrics 9: 722 728.

Buccheri S, Reljic R, Caccamo N, Ivanyi J, Singh M, Salerno A, Dieli F. 2007. IL-4 depletion enhances host resistance and passive IgA protection against tuberculosis infection in BALB/c mice. Eur J Immunol 37: 729-737.

Buccheri S, Reljic R, Caccamo N, Meraviglia S, Ivanyi J, Salerno A, Dieli F. 2009. Prevention of the post-chemotherapy relapse of tuberculous infection by combined immunotherapy. Tuberculosis (Edinb) 89: 91-94.

Carroll MV, Lack N, Sim E, Krarup A, Sim RB. 2009. Multiple routes of complement activation by Mycobacterium bovis BCG. Mol Immunol 46: 3367-3378.

Casadevall A. 1995. Antibody immunity and invasive fungal infections. Infect Immun 63: 4211-4218.

Casadevall A. 1998. Antibody-mediated protection against intracellular pathogens. Trends Microbiol 6: 102-107.

Casadevall A. 2003. Antibody-mediated immunity against intracellular pathogens: Two-dimensional thinking comes full circle. Infect Immun 71: 4225-4228.

Casadevall A. 2004. The methodology for determining the efficacy of antibody-mediated immunity. J Immunol Methods 291: 1-10.
Casadevall A, Pirofski LA. 2003. The damage-response framework of microbial pathogenesis. Nat Rev Microbiol 1: 17-24.

Casadevall A, Pirofski LA. 2012a. Immunoglobulins in defense, pathogenesis, and therapy of fungal diseases. Cell Host Microbe 11: 447-456.

Casadevall A, Pirofski LA. 2012b. A new synthesis for antibody-mediated immunity. Nat Immunol 13: 21-28.

Casadevall A, Dadachova E, Pirofski LA. 2004. Passive antibody therapy for infectious diseases. Nat Rev Microbiol 2: 695-703.

Casanova JL, Abel L. 2002. Genetic dissection of immunity to mycobacteria: The human model. Annu Rev Immunol 20: $581-620$.

Cassone A, Casadevall A. 2012. Recent progress in vaccines against fungal diseases. Curr Opin Microbiol 15: 427-433.

Chambers MA, Gavier-Widen D, Hewinson RG. 2004. Antibody bound to the surface antigen MPB83 of Mycobacterium bovis enhances survival against high dose and low dose challenge. FEMS Immunol Med Microbiol 41: 93-100.

Chan AC, Carter PJ. 2010. Therapeutic antibodies for autoimmunity and inflammation. Nat Rev Immunol 10: 301-316.

Chang-hong S, Xiao-wu W, Hai Z, Ting-fen Z, Li-Mei W, Zhi-kai X. 2008. Immune responses and protective efficacy of the gene vaccine expressing Ag85B and ESAT6 fusion protein from Mycobacterium tuberculosis. DNA Cell Biol 27: 199-207.

Chow SK, Smith C, MacCarthy T, Pohl MA, Bergman A, Casadevall A. 2013. Disease enhacing antibodies improve the efficacy of bacterial toxin-neutralizing antibodies. Cell Host Microbe 13: 417-428.

Ciurana CL, Zwart B, van Mierlo G, Hack CE. 2004. Complement activation by necrotic cells in normal plasma environment compares to that by late apoptotic cells and involves predominantly IgM. Eur J Immunol 34: 2609-2619.

Cliff JM, Lee JS, Constantinou N, Cho JE, Clark TG, Ronacher K, King EC, Lukey PT, Duncan K, Van Helden PD, et al. 2013. Distinct phases of blood gene expression pattern through tuberculosis treatment reflect modulation of the humoral immune response. J Infect Dis 207: $18-29$.

Clynes R. 2005. Immune complexes as therapy for autoimmunity. J Clin Invest 115: 25-27.

Colditz GA, Brewer TF, Berkey CS, Wilson ME, Burdick E, Fineberg HV, Mosteller F. 1994. Efficacy of BCG vaccine in the prevention of tuberculosis. Meta-analysis of the published literature. JAMA 271: 698-702.

Collins FM. 1974. Vaccines and cell-mediated immunity. Bacteriol Rev 38: 371-402.

Conley ME, Dobbs AK, Farmer DM, Kilic S, Paris K, Grigoriadou S, Coustan-Smith E, Howard V, Campana D. 2009. Primary B cell immunodeficiencies: Comparisons and contrasts. Annu Rev Immunol 27: 199-227.

Conti S, Fanti F, Magliani W, Gerloni M, Bertolotti D, Salati A, Cassone A, Polonelli L. 1998. Mycobactericidal activity of human natural, monoclonal, and recombinant yeast killer toxin-like antibodies. J Infect Dis 177: 807-811. 
J.M. Achkar et al.

Cooper AM. 2009. Cell-mediated immune responses in tuberculosis. Annu Rev Immunol 27: 393-422.

Corominas M, Cardona V, Gonzalez L, Cayla JA, Rufi G, Mestre M, Buendia E. 2004. B-lymphocytes and co-stimulatory molecules in Mycobacterium tuberculosis infection. Int J Tuberc Lung Dis 8: 98-105.

Costello AM, Kumar A, Narayan V, Akbar MS, Ahmed S, Abou-Zeid C, Rook GA, Stanford J, Moreno C. 1992 Does antibody to mycobacterial antigens, including lipoarabinomannan, limit dissemination in childhood tuberculosis? Trans R Soc Trop Med Hyg 86: 686-692.

Cruz AT, Starke JR. 2007. Clinical manifestations of tuberculosis in children. Paediatr Respir Rev 8: 107-117.

Cubas RA, Mudd JC, Savoye AL, Perreau M, van Grevenynghe J, Metcalf T, Connick E, Meditz A, Freeman GJ, Abesada-Terk G Jr., et al. 2013. Inadequate T follicular cell help impairs B cell immunity during HIV infection. Nat Med 19: 494-499.

Czuczman MS, Gregory SA. 2010. The future of CD20 monoclonal antibody therapy in B-cell malignancies. Leuk Lymphoma 51: 983-994.

Dayal R, Singh A, Katoch VM, Joshi B, Chauhan DS, Singh P, Kumar G, Sharma VD. 2008. Serological diagnosis of tuberculosis. Indian J Pediatr 75: 1219-1221.

de Valliere S, Abate G, Blazevic A, Heuertz RM, Hoft DF 2005. Enhancement of innate and cell-mediated immunity by antimycobacterial antibodies. Infect Immun 73: 6711-6720.

Dhodapkar KM, Kaufman JL, Ehlers M, Banerjee DK, Bonvini E, Koenig S, Steinman RM, Ravetch JV, Dhodapkar MV. 2005. Selective blockade of inhibitory Fcy receptor enables human dendritic cell maturation with IL-12p70 production and immunity to antibody-coated tumor cells. Proc Natl Acad Sci 102: 2910-2915.

Donald PR, Marais BJ, Barry CE, 3rd. 2010. Age and the epidemiology and pathogenesis of tuberculosis. Lancet 375: $1852-1854$.

Driver ER, Ryan GJ, Hoff DR, Irwin SM, Basaraba RJ, Kramnik I, Lenaerts AJ. 2012. Evaluation of a mouse model of necrotic granuloma formation using $\mathrm{C} 3 \mathrm{HeB} / \mathrm{FeJ}$ mice for testing of drugs against Mycobacterium tuberculosis. Antimicrob Agents Chemother 56: 3181-3195.

Dromer F, Charreire J, Contrepois A, Carbon C, Yeni P. 1987. Protection of mice against experimental cryptococcosis by anti-Cryptococcus neoformans monoclonal antibody. Infect Immun 55: 749-752.

Encinales L, Zuniga J, Granados-Montiel J, Yunis M, Granados J, Almeciga I, Clavijo O, Awad C, Collazos V, VargasRojas MI, et al. 2010. Humoral immunity in tuberculin skin test anergy and its role in high-risk persons exposed to active tuberculosis. Mol Immunol 47: 1066-1073.

Ernst JD. 2012. The immunological life cycle of tuberculosis. Nat Rev Immunol 12: 581-591.

Fairchok MP, Rouse JH, Morris SL. 1995. Age-dependent humoral responses of children to mycobacterial antigens. Clin Diagn Lab Immunol 2: 443-447.

Fletcher HA, Tanner R, Wallis RS, Meyer J, Manjaly ZR, Harris S, Satti I, Silver RF, Hoft D, Kampmann B, et al. 2013. Inhibition of mycobacterial growth in vitro following primary but not secondary vaccination with BCG. Clin Vaccine Immunol 20: 1683-1689.
Flynn JL, Chan J. 2001. Immunology of tuberculosis. Annu Rev Immunol 19: 93-129.

Flynn JL, Klein E. 2010. Pulmonary tuberculosis in monkeys. In A color atlas of comparative pulmonary tuberculosis histopathology (ed. Leong J). Taylor \& Francis, Oxford.

Fortin A, Abel L, Casanova JL, Gros P. 2007. Host genetics of mycobacterial diseases in mice and men: Forward genetic studies of BCG-osis and tuberculosis. Ann Rev Genomics Hum Genet 8: 163-192.

Giri PK, Verma I, Khuller GK. 2006. Enhanced immunoprotective potential of Mycobacterium tuberculosis Ag85 complex protein based vaccine against airway Mycobacterium tuberculosis challenge following intranasal administration. FEMS Immunol Med Microbiol 47: 233-241.

Glatman-Freedman A. 2006. The role of antibody-mediated immunity in defense against Mycobacterium tuberculosis: Advances toward a novel vaccine strategy. Tuberculosis (Edinb) 86: 191-197.

Glatman-Freedman A, Casadevall A. 1998. Serum therapy for tuberculosis revisited: Reappraisal of the role of antibody-mediated immunity against Mycobacterium tuberculosis. Clin Microbiol Rev 11: 514-532.

Glatman-Freedman A, Mednick AJ, Lendvai N, Casadevall A. 2000. Clearance and organ distribution of Mycobacterium tuberculosis lipoarabinomannan (LAM) in the presence and absence of LAM-binding immunoglobulin M. Infect Immun 68: 335-341.

Glatman-Freedman A, Casadevall A, Dai Z, Jacobs WR Jr., Li A, Morris SL, Navoa JA, Piperdi S, Robbins JB, Schneerson R, et al. 2004. Antigenic evidence of prevalence and diversity of Mycobacterium tuberculosis arabinomannan. J Clin Microbiol 42: 3225-3231.

Gonzalez-Juarrero M, Turner OC, Turner J, Marietta P, Brooks JV, Orme IM. 2001. Temporal and spatial arrangement of lymphocytes within lung granulomas induced by aerosol infection with Mycobacterium tuberculosis. Infect Immun 69: 1722-1728.

Good RA, Zak SJ. 1956. Disturbances in $\gamma$ globulin synthesis as experiments of nature. Pediatr Rev 18: 109-149.

Grosset J. 2003. Mycobacterium tuberculosis in the extracellular compartment: An underestimated adversary. Antimicrob Agents Chemother 47: 833-836.

Grover A, Ahmed MF, Singh B, Verma I, Sharma P, Khuller GK. 2006. A multivalent combination of experimental antituberculosis DNA vaccines based on Ag85B and regions of difference antigens. Microbes Infect 8: 2390 2399.

Guirado E, Amat I, Gil O, Diaz J, Arcos V, Caceres N, Ausina V, Cardona PJ. 2006. Passive serum therapy with polyclonal antibodies against Mycobacterium tuberculosis protects against post-chemotherapy relapse of tuberculosis infection in SCID mice. Microbes Infect 8: 1252-1259.

Gupta S, Bhatia R, Datta KK. 1997. Serological diagnosis of childhood tuberculosis by estimation of mycobacterial antigen 60-specific immunoglobulins in the serum. Tuber Lung Dis 78: 21-27.

Hamasur B, Haile M, Pawlowski A, Schroder U, Williams A, Hatch G, Hall G, Marsh P, Kallenius G, Svenson SB. 2003. Mycobacterium tuberculosis arabinomannan-protein conjugates protect against tuberculosis. Vaccine 21: 4081-4093. 
Hamasur B, Haile M, Pawlowski A, Schroder U, Kallenius G, Svenson SB. 2004. A mycobacterial lipoarabinomannan specific monoclonal antibody and its $\mathrm{F}\left(\mathrm{ab}^{\prime}\right)$ fragment prolong survival of mice infected with Mycobacterium tuberculosis. Clin Exp Immunol 138: 30-38.

Hernandez J, Velazquez C, Valenzuela O, Robles-Zepeda R, Ruiz-Bustos E, Navarro M, Garibay-Escobar A. 2010. Low number of peripheral blood B lymphocytes in patients with pulmonary tuberculosis. Immunol Invest 39: 197-205.

Hetland G, Wiker HG, Hogasen K, Hamasur B, Svenson SB, Harboe M. 1998. Involvement of antilipoarabinomannan antibodies in classical complement activation in tuberculosis. Clin Diagn Lab Immunol 5: 211-218.

Hoff DR, Ryan GJ, Driver ER, Ssemakulu CC, De Groote MA, Basaraba RJ, Lenaerts AJ. 2011. Location of intraand extracellular $M$. tuberculosis populations in lungs of mice and guinea pigs during disease progression and after drug treatment. PLoS ONE 6: e17550.

Huygen K, Content J, Denis O, Montgomery DL, Yawman AM, Deck RR, DeWitt CM, Orme IM, Baldwin S, D'Souza C, et al. 1996. Immunogenicity and protective efficacy of a tuberculosis DNA vaccine. Nat Med 2: 893-898.

Igietseme JU, Eko FO, He Q, Black CM. 2004. Antibody regulation of T-cell immunity: Implications for vaccine strategies against intracellular pathogens. Expert Rev Vaccines 3: $23-34$.

Ireton GC, Greenwald R, Liang H, Esfandiari J, Lyashchenko KP, Reed SG. 2010. Identification of Mycobacterium tuberculosis antigens of high serodiagnostic value. Clin Vaccine Immunol 17: 1539-1547.

Isaacs D. 2013. Infectious risks associated with biologics. Adv Exp Med Biol 764: 151-158.

Johnson CM, Cooper AM, Frank AA, Bonorino CB, Wysoki LJ, Orme IM. 1997. Mycobacterium tuberculosis aerogenic rechallenge infections in B cell-deficient mice. Tuber Lung Dis 78: $257-261$.

Kalergis AM, Ravetch JV. 2002. Inducing tumor immunity through the selective engagement of activating Fc $\gamma$ receptors on dendritic cells. J Exp Med 195: 1653-1659.

Karakousis PC, Yoshimatsu T, Lamichhane G, Woolwine SC, Nuermberger EL, Grosset J, Bishai WR. 2004. Dormancy phenotype displayed by extracellular Mycobacterium tuberculosis within artificial granulomas in mice. J Exp Med 200: 647-657.

Keane J, Gershon S, Wise RP, Mirabile-Levens E, Kasznica J, Schwieterman WD, Siegel JN, Braun MM. 2001. Tuberculosis associated with infliximab, a tumor necrosis factor $\alpha$-neutralizing agent. N Engl J Med 345: 1098-1104.

Keyser A, Troudt JM, Taylor JL, Izzo AA. 2011. BCG substrains induce variable protection against virulent pulmonary Mycobacterium tuberculosis infection, with the capacity to drive Th2 immunity. Vaccine 29: 9308-9315.

Kim MJ, Wainwright HC, Locketz M, Bekker LG, Walther GB, Dittrich C, Visser A, Wang W, Hsu FF, Wiehart U, et al. 2010. Caseation of human tuberculosis granulomas correlates with elevated host lipid metabolism. EMBO Mol Med 2: 258-274.

Kohama H, Umemura M, Okamoto Y, Yahagi A, Goga H, Harakuni T, Matsuzaki G, Arakawa T. 2008. Mucosal immunization with recombinant heparin-binding hae- magglutinin adhesin suppresses extrapulmonary dissemination of Mycobacterium bovis bacillus Calmette-Guérin (BCG) in infected mice. Vaccine 26: 924-932.

Kondratieva TK, Rubakova EI, Linge IA, Evstifeev VV, Majorov KB, Apt AS. 2010. B cells delay neutrophil migration toward the site of stimulus: Tardiness critical for effective bacillus Calmette-Guérin vaccination against tuberculosis infection in mice. J Immunol 184: 1227-1234.

Kozakiewicz L, Chen Y, Xu J, Wang Y, Dunussi-Joannopoulos K, Ou Q, Flynn JL, Porcelli SA, Jacobs WR Jr., Chan J. 2013a. B cells regulate neutrophilia during Mycobacterium tuberculosis infection and BCG vaccination by modulating the interleukin-17 response. PLoS Pathog 9: e1003472.

Kozakiewicz L, Phuah J, Flynn J, Chan J. 2013b. The role of B cells and humoral immunity in Mycobacterium tuberculosis infection. Adv Exp Med Biol 783: 225-250.

Kunnath-Velayudhan S, Salamon H, Wang HY, Davidow AL, Molina DM, Huynh VT, Cirillo DM, Michel G, Talbot EA, Perkins MD, et al. 2010. Dynamic antibody responses to the Mycobacterium tuberculosis proteome. Proc Natl Acad Sci 107: 14703-14708.

Kunnath-Velayudhan S, Davidow AL, Wang HY, Molina DM, Huynh VT, Salamon H, Pine R, Michel G, Perkins MD, Xiaowu L, et al. 2012. Proteome-scale antibody responses and outcome of Mycobacterium tuberculosis infection in nonhuman primates and in tuberculosis patients. J Infect Dis 206: 697-705.

Leemans JC, Juffermans NP, Florquin S, van Rooijen N, Vervoordeldonk MJ, Verbon A, van Deventer SJ, van der Poll T. 2001. Depletion of alveolar macrophages exerts protective effects in pulmonary tuberculosis in mice. $J$ Immunol 166: 4604-4611.

Leemans JC, Thepen T, Weijer S, Florquin S, van Rooijen N, van de Winkel JG, van der Poll T. 2005. Macrophages play a dual role during pulmonary tuberculosis in mice. $J$ Infect Dis 191: 65-74.

Lewinsohn DA, Gold MC, Lewinsohn DM. 2011. Views of immunology: Effector T cells. Immunol Rev 240: 25-39.

Lin PL, Rodgers M, Smith L, Bigbee M, Myers A, Bigbee C, Chiosea I, Capuano SV, Fuhrman C, Klein E, et al. 2009. Quantitative comparison of active and latent tuberculosis in the cynomolgus macaque model. Infect Immun 77: $4631-4642$.

Locci M, Havenar-Daughton C, Landais E, Wu J, Kroenke MA, Arlehamn CL, Su LF, Cubas R, Davis MM, Sette A, et al. 2013. Human circulating $\mathrm{PD}^{+} \mathrm{CXCR}^{-} \mathrm{CXCR}^{+}$ memory Tfh cells are highly functional and correlate with broadly neutralizing HIV antibody responses. Immunity 39: 758-769.

Lopez Y, Yero D, Falero-Diaz G, Olivares N, Sarmiento ME, Sifontes S, Solis RL, Barrios JA, Aguilar D, HernandezPando R, et al. 2009. Induction of a protective response with an IgA monoclonal antibody against Mycobacterium tuberculosis $16 \mathrm{kDa}$ protein in a model of progressive pulmonary infection. Int J Med Microbiol 299: 447-452.

Lux A, Aschermann S, Biburger M, Nimmerjahn F. 2010. The pro and anti-inflammatory activities of immunoglobulin G. Ann Rheum Dis 69 (Suppl 1): i92-i96.

Lyashchenko K, Colangeli R, Houde M, Al Jahdali H, Menzies D, Gennaro ML. 1998. Heterogeneous antibody responses in tuberculosis. Infect Immun 66: 3936-3940. 
J.M. Achkar et al.

Lyashchenko KP, Greenwald R, Esfandiari J, Greenwald D, Nacy CA, Gibson S, Didier PJ, Washington M, Szczerba P, Motzel S, et al. 2007. PrimaTB STAT-PAK assay, a novel, rapid lateral-flow test for tuberculosis in nonhuman primates. Clin Vaccine Immunol 14: 1158-1164.

Lyashchenko KP, Greenwald R, Esfandiari J, Chambers MA, Vicente J, Gortazar C, Santos N, Correia-Neves M, Buddle BM, Jackson R, et al. 2008. Animal-side serologic assay for rapid detection of Mycobacterium bovis infection in multiple species of free-ranging wildlife. Vet Microbiol 132: 283-292.

Lyashchenko KP, Greenwald R, Esfandiari J, Mikota S, Miller M, Moller T, Vogelnest L, Gairhe KP, Robbe-Austerman S, Gai J, et al. 2012. Field application of serodiagnostics to identify elephants with tuberculosis prior to case confirmation by culture. Clin Vaccine Immunol 19: 1269-1275

Ma CS, Deenick EK, Batten M, Tangye SG. 2012. The origins, function, and regulation of T follicular helper cells. J Exp Med 209: 1241-1253.

Maglione PJ, Chan J. 2009. How B cells shape the immune response against Mycobacterium tuberculosis. Eur J Immunol 39: 676-686.

Maglione PJ, Xu J, Chan J. 2007. B cells moderate inflammatory progression and enhance bacterial containment upon pulmonary challenge with Mycobacterium tuberculosis. J Immunol 178: 7222-7234.

Maglione PJ, Xu J, Casadevall A, Chan J. 2008. Fc $\gamma$ receptors regulate immune activation and susceptibility during Mycobacterium tuberculosis infection. J Immunol 180: 3329-3338.

Malik ZA, Denning GM, Kusner DJ. 2000. Inhibition of $\mathrm{Ca}^{2+}$ signaling by Mycobacterium tuberculosis is associated with reduced phagosome-lysosome fusion and increased survival within human macrophages. J Exp Med 191: $287-302$.

Manivannan S, Rao NV, Ramanathan VD. 2012. Role of complement activation and antibody in the interaction between Mycobacterium tuberculosis and human macrophages. Indian J Exp Biol 50: 542-550.

McClelland EE, Nicola AM, Prados-Rosales R, Casadevall A. 2010. Ab binding alters gene expression in Cryptococcus neoformans and directly modulates fungal metabolism. $J$ Clin Invest 120: 1355-1361.

Moir S, Fauci AS. 2009. B cells in HIV infection and disease. Nat Rev Immunol 9: 235-245.

Mossalayi MD, Vouldoukis I, Mamani-Matsuda M, Kauss T, Guillon J, Maugein J, Moynet D, Rambert J, Desplat V, Mazier D, et al. 2009. CD23 mediates antimycobacterial activity of human macrophages. Infect Immun 77: 5537 5542.

Nimmerjahn F, Ravetch JV. 2008. Fc $\gamma$ receptors as regulators of immune responses. Nat Rev Immunol 8: 34-47.

Niu H, Hu L, Li Q, Da Z, Wang B, Tang K, Xin Q, Yu H, Zhang Y, Wang Y, et al. 2011. Construction and evaluation of a multistage Mycobacterium tuberculosis subunit vaccine candidate Mtb10.4-HspX. Vaccine 29: 9451-9458.

North RJ, LaCourse R, Ryan L, Gros P. 1999. Consequence of Nramp1 deletion to Mycobacterium tuberculosis infection in mice. Infect Immun 67: 5811-5814.

Nosanchuk JD, Steenbergen JN, Shi L, Deepe GS Jr., Casadevall A. 2003. Antibodies to a cell surface histone-like protein protect against Histoplasma capsulatum. J Clin Invest 112: 1164-1175.

Nussbaum G, Yuan R, Casadevall A, Scharff MD. 1996. Immunoglobulin G3 blocking antibodies to the fungal pathogen Cryptococcus neoformans. J Exp Med 183: 1905-1909.

Olivares N, Leon A, Lopez Y, Puig A, Cadiz A, Falero G, Martinez M, Sarmiento ME, Farinas M, Infante JF, et al. 2006. The effect of the administration of human $\gamma$ globulins in a model of BCG infection in mice. Tuberculosis (Edinb) 86: 268-272.

Ottenhoff TH. 2012. New pathways of protective and pathological host defense to mycobacteria. Trends Microbiol 20: $419-428$.

Ottenhoff TH, Kaufmann SH. 2012. Vaccines against tuberculosis: Where are we and where do we need to go? PLoS Pathog 8: e1002607.

Palma C, Iona E, Giannoni F, Pardini M, Brunori L, Fattorini L, Del Giudice G, Cassone A. 2008. The LTK63 adjuvant improves protection conferred by Ag85B DNA-protein prime-boosting vaccination against Mycobacterium tuberculosis infection by dampening IFN- $\gamma$ response. Vaccine 26: 4237-4243.

Pethe K, Alonso S, Biet F, Delogu G, Brennan MJ, Locht C, Menozzi FD. 2001. The heparin-binding haemagglutinin of $M$. tuberculosis is required for extrapulmonary dissemination. Nature 412: 190-194.

Pillai S. 2013. Love the one you're with: The HIV, B cell and TFH cell triangle. Nat Med 19: 401-402.

Pohl MA, Rivera J, Nakouzi A, Chow SK, Casadevall A. 2013. Combinations of antibodies to anthrax toxin manifest emergent properties in neutralization assays. Infect Immun 81: 1880-1888.

Rafiq K, Bergtold A, Clynes R. 2002. Immune complex-mediated antigen presentation induces tumor immunity. J Clin Invest 110: 71-79.

Roca FJ, Ramakrishnan L. 2013. TNF dually mediates resistance and susceptibility to mycobacteria via mitochondrial reactive oxygen species. Cell 153: 521-534.

Rodriguez A, Tjarnlund A, Ivanji J, Singh M, Garcia I, Williams A, Marsh PD, Troye-Blomberg M, Fernandez C. 2005. Role of IgA in the defense against respiratory infections IgA deficient mice exhibited increased susceptibility to intranasal infection with Mycobacterium bovis BCG. Vaccine 23: 2565-2572.

Roy E, Stavropoulos E, Brennan J, Coade S, Grigorieva E, Walker B, Dagg B, Tascon RE, Lowrie DB, Colston MJ, et al. 2005. Therapeutic efficacy of high-dose intravenous immunoglobulin in Mycobacterium tuberculosis infection in mice. Infect Immun 73: 6101-6109.

Rubbert-Roth A. 2012. Assessing the safety of biologic agents in patients with rheumatoid arthritis. Rheumatology (Oxford) 51 (Suppl 5): v38-v47.

Ruderman EM. 2012. Overview of safety of non-biologic and biologic DMARDs. Rheumatology (Oxford) 51 (Suppl 6): vi37-vi43.

Russo RT, Mariano M. 2010. B-1 cell protective role in murine primary Mycobacterium bovis bacillus CalmetteGuérin infection. Immunobiology 215: 1005-1014.

Sada E, Ferguson LE, Daniel TM. 1990. An ELISA for the serodiagnosis of tuberculosis using a 30,000-Da native 
antigen of Mycobacterium tuberculosis. J Infect Dis 162: 928-931.

Saylor C, Dadachova E, Casadevall A. 2009. Monoclonal antibody-based therapies for microbial diseases. Vaccine 27 (Suppl 6): G38-G46.

Schmitt N, Ueno H. 2013. Blood Th cells come with colors. Immunity 39: 629-630.

Schoels M, Aletaha D, Smolen JS, Wong JB. 2012. Comparative effectiveness and safety of biological treatment options after tumour necrosis factor alpha inhibitor failure in rheumatoid arthritis: Systematic review and indirect pairwise meta-analysis. Ann Rheum Dis 71: 1303-1308.

Schwebach JR. 2002. "The carbohydrate surface of $M$. tuberculosis: Antigenicity and antibody immunity." Thesis. Sue Golding Graduate Division of Medical Sciences. Albert Einstein College of Medicine, Bronx, NY.

Slight SR, Rangel-Moreno J, Gopal R, Lin Y, Fallert Junecko BA, Mehra S, Selman M, Becerril-Villanueva E, BaqueraHeredia J, Pavon L, et al. 2013. CXCR5 ${ }^{+}$T helper cells mediate protective immunity against tuberculosis. J Clin Invest 123: 712-726.

Smith MB, Boyars MC, Veasey S, Woods GL. 2000. Generalized tuberculosis in the acquired immune deficiency syndrome. Arch Pathol Lab Med 124: 1267-1274.

Suga M, Tanaka F, Muranaka H, Nishikawa H, Ando M. 1996. Effect of antibacterial antibody on bactericidal activities of superoxide and lysosomal enzyme from alveolar macrophages in rabbits. Respirology 1: 127-132.

Sutherland JS, Loxton AG, Haks MC, Kassa D, Ambrose L, Lee JS, Ran L, van Baarle D, Maertzdorf J, Howe R, et al. 2013. Differential gene expression of activating Fc $\gamma$ receptor classifies active tuberculosis regardless of human immunodeficiency virus status or ethnicity. Clin Microbiol Infect 20: O230-O238.

Tameris MD, Hatherill M, Landry BS, Scriba TJ, Snowden MA, Lockhart S, Shea JE, McClain JB, Hussey GD, Hanekom WA, et al. 2013. Safety and efficacy of MVA85A, a new tuberculosis vaccine, in infants previously vaccinated with BCG: A randomised, placebo-controlled phase 2b trial. Lancet 381: 1021-1028

Teitelbaum R, Glatman-Freedman A, Chen B, Robbins JB, Unanue E, Casadevall A, Bloom BR. 1998. A mAb recognizing a surface antigen of Mycobacterium tuberculosis enhances host survival. Proc Natl Acad Sci 95: $15688_{-}$ 15693.

Teixeira FM, Teixeira HC, Ferreira AP, Rodrigues MF, Azevedo V, Macedo GC, Oliveira SC. 2006. DNA vaccine using Mycobacterium bovis Ag85B antigen induces partial protection against experimental infection in BALB/c mice. Clin Vaccine Immunol 13: 930-935.

Tjarnlund A, Rodriguez A, Cardona PJ, Guirado E, Ivanyi J, Singh M, Troye-Blomberg M, Fernandez C. 2006. Polymeric IgR knockout mice are more susceptible to mycobacterial infections in the respiratory tract than wild-type mice. Int Immunol 18: 807-816.

Townsend MJ, Monroe JG, Chan AC. 2010. B-cell targeted therapies in human autoimmune diseases: An updated perspective. Immunol Rev 237: 264-283.

Tsai MC, Chakravarty S, Zhu G, Xu J, Tanaka K, Koch C, Tufariello J, Flynn J, Chan J. 2006. Characterization of the tuberculous granuloma in murine and human lungs: Cellular composition and relative tissue oxygen tension. Cell Microbiol 8: 218-232.

Ulrichs T, Kosmiadi GA, Trusov V, Jorg S, Pradl L, Titukhina M, Mishenko V, Gushina N, Kaufmann SH. 2004. Human tuberculous granulomas induce peripheral lymphoid follicle-like structures to orchestrate local host defence in the lung. J Pathol 204: 217-228.

Vinuesa CG. 2012. HIV and T follicular helper cells: A dangerous relationship. J Clin Invest 122: 3059-3062.

Vinuesa CG, Tangye SG, Moser B, Mackay CR. 2005. Follicular B helper T cells in antibody responses and autoimmunity. Nat Rev Immunol 5: 853-865.

Vordermeier HM, Venkataprasad N, Harris DP, Ivanyi J. 1996. Increase of tuberculous infection in the organs of B cell-deficient mice. Clin Exp Immunol 106: 312-316.

Vouldoukis I, Mazier D, Moynet D, Thiolat D, Malvy D, Mossalayi MD. 2011. IgE mediates killing of intracellular Toxoplasma gondii by human macrophages through CD23-dependent, interleukin-10 sensitive pathway. PLoS ONE 6: e18289.

Weiner LM, Surana R, Wang S. 2010. Monoclonal antibodies: Versatile platforms for cancer immunotherapy. Nat Rev Immunol 10: 317-327.

Williams A, Reljic R, Naylor I, Clark SO, Falero-Diaz G, Singh M, Challacombe S, Marsh PD, Ivanyi J. 2004. Passive protection with immunoglobulin A antibodies against tuberculous early infection of the lungs. Immunology 111: 328-333.

Xue T, Stavropoulos E, Yang M, Ragno S, Vordermeier M, Chambers M, Hewinson G, Lowrie DB, Colston MJ, Tascon RE. 2004. RNA encoding the MPT83 antigen induces protective immune responses against Mycobacterium tuberculosis infection. Infect Immun 72: 6324-6329.

Yano M, Gohil S, Coleman JR, Manix C, Pirofski LA. 2011. Antibodies to Streptococcus pneumoniae capsular polysaccharide enhance pneumococcal quorum sensing. mBio 2: e0076-11.

Yao S, Huang D, Chen CY, Halliday L, Wang RC, Chen ZW. 2014. $\mathrm{CD}^{+} \mathrm{T}$ cells contain early extrapulmonary tuberculosis (TB) dissemination and rapid TB progression and sustain multieffector functions of $\mathrm{CD}^{+} \mathrm{T}$ and $\mathrm{CD} 3-$ lymphocytes: Mechanisms of $\mathrm{CD}^{+}{ }^{+} \mathrm{T}$ cell immunity. $J$ Immunol 192: 2120-2132.

Yu X, Prados-Rosales R, Jenny-Avital ER, Sosa K, Casadevall A, Achkar JM. 2012. Comparative evaluation of profiles of antibodies to mycobacterial capsular polysaccharides in tuberculosis patients and controls stratified by HIV status. Clin Vaccine Immunol 19: 198-208.

Zhang M, Zheng X, Zhang J, Zhu Y, Zhu X, Liu H, Zeng M, Graner MW, Zhou B, Chen X. 2012. CD $19^{+} \mathrm{CD} 1 \mathrm{~d}^{+} \mathrm{CD}^{+}$ $B$ cell frequencies are increased in patients with tuberculosis and suppress Th17 responses. Cell Immunol 274: 89-97.

Ziegenbalg A, Prados-Rosales R, Jenny-Avital ER, Kim RS, Casadevall A, Achkar JM. 2013. Immunogenicity of mycobacterial vesicles in humans: Identification of a new tuberculosis antibody biomarker. Tuberculosis (Edinb) 93: $448-455$. 


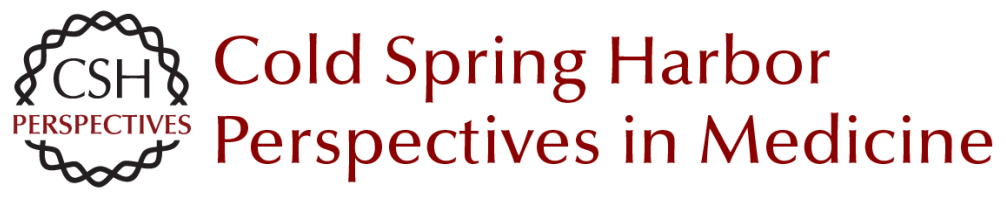

\section{Role of B Cells and Antibodies in Acquired Immunity against Mycobacterium tuberculosis}

Jacqueline M. Achkar, John Chan and Arturo Casadevall

Cold Spring Harb Perspect Med 2015; doi: 10.1101/cshperspect.a018432 originally published online October 9, 2014

\section{Subject Collection Tuberculosis}

\section{Transmission and Institutional Infection Control of Tuberculosis Edward A. Nardell \\ Innate and Adaptive Cellular Immune Responses to Mycobacterium tuberculosis Infection Katrin D. Mayer-Barber and Daniel L. Barber}

Tuberculosis Comorbidity with Communicable and Noncommunicable Diseases

Matthew Bates, Ben J. Marais and Alimuddin Zumla

Host-Directed Therapies for Tuberculosis David M. Tobin

Immunity and Immunopathology in the Tuberculous Granuloma

Antonio J. Pagán and Lalita Ramakrishnan

Tuberculosis Drug Development: History and Evolution of the Mechanism-Based Paradigm? Sumit Chakraborty and Kyu Y. Rhee

\section{Genetic Approaches to Facilitate Antibacterial Drug Development Dirk Schnappinger}

The Tuberculosis Drug Discovery and Development Pipeline and Emerging Drug Targets Khisimuzi Mdluli, Takushi Kaneko and Anna Upton
Clinical Aspects of Adult Tuberculosis

Robert Loddenkemper, Marc Lipman and Alimuddin Zumla

Advances in Diagnostic Assays for Tuberculosis Stephen D. Lawn

Diagnosis and Management of Latent

Tuberculosis Infection

Laura Muñoz, Helen R. Stagg and Ibrahim Abubakar

Mycobacterial Growth Iria Uhía, Kerstin J. Williams, Vahid Shahrezaei, et al.

Multidrug-Resistant Tuberculosis and Extensively

Drug-Resistant Tuberculosis

Kwonjune J. Seung, Salmaan Keshavjee and Michael L. Rich

The Mycobacterial Cell Wall--Peptidoglycan and

Arabinogalactan

Luke J. Alderwick, James Harrison, Georgina S. Lloyd, et al.

Tuberculosis and HIV Coinfection Judith Bruchfeld, Margarida Correia-Neves and Gunilla Källenius

Imaging in Tuberculosis Jamshed B. Bomanji, Narainder Gupta, Parveen Gulati, et al.

For additional articles in this collection, see http://perspectivesinmedicine.cshlp.org/cgi/collection/ 